UCRL-TR-214723

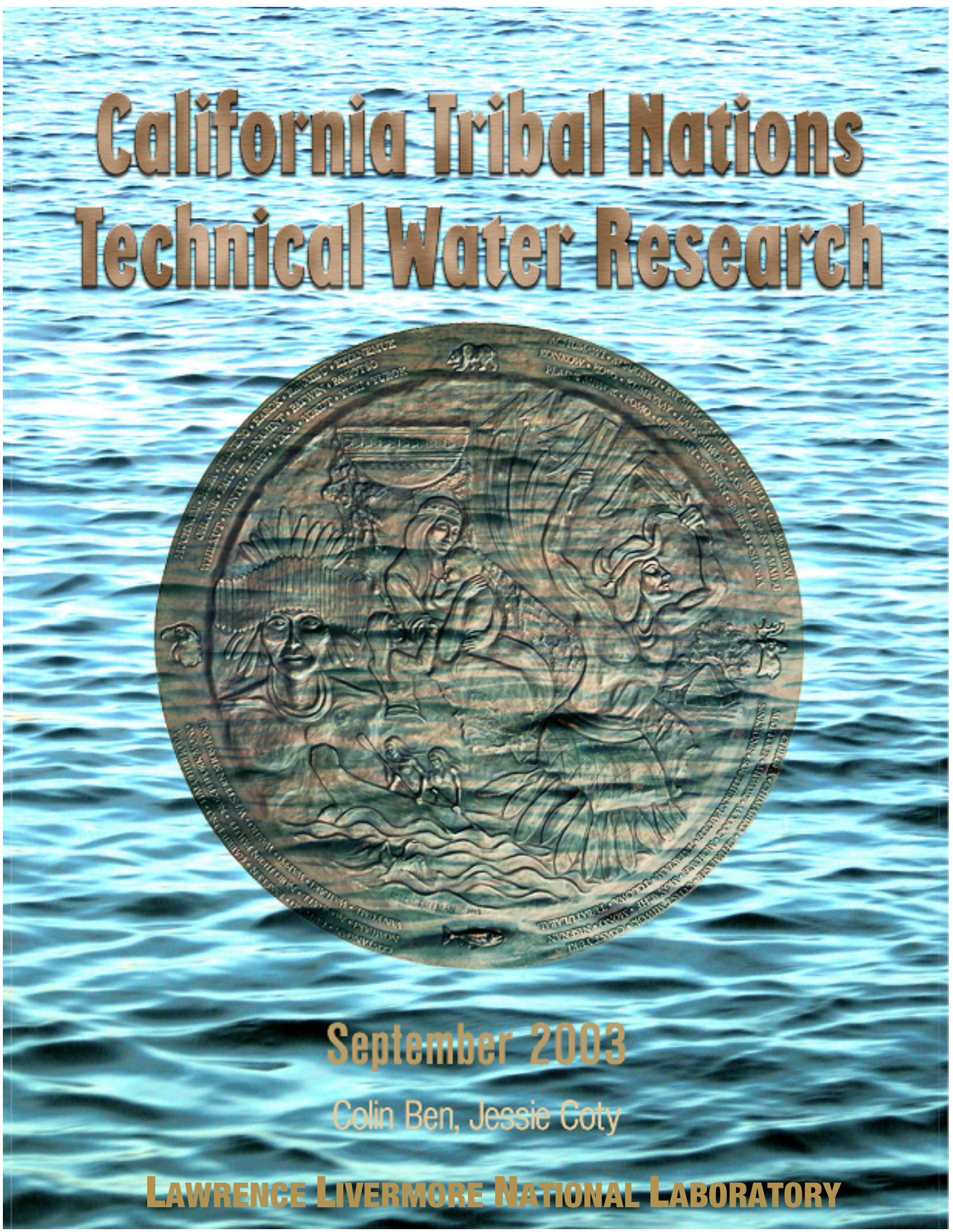




\section{DISCLAIMER}

This document was prepared as an account of work sponsored by an agency of the United States Government. Neither the United States Government nor the University of California nor any of their employees, makes any warranty, express or implied, or assumes any legal liability or responsibility for the accuracy, completeness, or usefulness of any information, apparatus, product, or process disclosed, or represents that its use would not infringe privately owned rights. Reference herein to any commercial product, process, or service by trade name, trademark, manufacturer, or otherwise does not necessarily constitute or imply its endorsement, recommendation, or favoring by the United States Government of the University of California. The views and opinions of authors expressed herein do not necessarily state or reflect those of the United States Government or the University of California, and shall not be used for advertising or product endorsement purposes.

This work was performed under the auspices of the U.S. Department of Energy by University of California Lawrence Livermore National Laboratory under contract No. W7405-Eng-48. 


\title{
California Tribal Nations TECHNICAL WATER RESEARCH
}

September, 2003

\author{
Colin Ben \\ Jessie Coty
}




\section{TABLE OF CONTENTS}

INTRODUCTION 6

Research Constraints 7

Methodology 8

Geographic Regions 11

Categories of Water Programs 11

Number of Tribes per Region and Category 12

Selection Method Results: Representative Tribes 12

Feedback on Selection Method 13

Research Results 14

Technical Water Research Issues 14

Demographics and Context 16

Proposed Roundtable Format 19

RECOMMENDATIONS 20

CONCLUSIONS 20

RefERENCES 21

Appendix A: Selected Tribes, Regions \& Water Programs 22

Appendix B: List of California Tribes and Key Contacts 27

Appendix C: Detalled Research Results for Tribes 41

Appendix D: Presentation of Tribal Report 47

ApPendix E: Suggested ResOURCES 70

Appendix F: Key Websites 71 


\section{Acknowledgements}

I would like to thank Lawrence Livermore National Laboratory's Energy \& Environment Directorate and the American Indian Program Field Office for funding this summer research project. I especially extend my gratitude to Jessie Coty for her guidance and direction of my research and Steve Grey for his support to work on such a project. In addition, I would like to acknowledge the valuable assistance from many federal agencies that include: the Bureau of Indian Affairs - Pacific Region, U.S. Environmental Protection Agency Region IV Regional Project Officers, and California Area Indian Health ServicesEnvironmental Health Services. Most importantly, I would like to thank the California Native American Tribal staff that I interviewed to collect and assemble the most current tribal data.

Colin Ben, LLNL Energy \& Environment Intern, 2003 
Federally Recognized Tribes: A government-to-government relationship exists between the federally recognized tribes and the U.S. government. Federally recognized tribes are eligible to participate in federal programs and receive federal aid from these programs. Federally recognized tribes have their land "held in trust".

Non-Federally Recognized Tribes: No government-to-government relationship exists between the tribes and the U.S. government. Non-federally recognized tribes are not eligible to participate in federal programs and receive federal aid from these programs. Non-federally recognized tribes do not own any land "held in trust" by the U.S. government. Non-federally recognized tribes may petition for Federal Acknowledgement within the Department of Interior.

State Recognized Tribes: A relationship exists between the state recognized tribes and the state government; this acknowledgement is largely symbolic. No government-to-government relationship exists between the state recognized tribes and the U.S. government. State recognized tribes are not eligible for participation in federal programs and receive federal aid from these programs. However, state recognized tribes are eligible for state aid (noted to occur more rarely). 


\section{INTRODUCTION}

This research focused on identifying the key technical water issues of federally recognized California Native American tribes, the context within which these water issues arise for the tribes, and an appropriate format for potentially opening further dialogue on water research issues between the tribes and Lawrence Livermore National Laboratory (LLNL) scientists. At LLNL, a Water Quality and Resource Management Issues Workshop held in January of 2003 resulted in multiple recommendations, one proposing a LLNL dialogue with California tribes to further inform LLNL's prioritization of water issues based on identified needs across national sectors.

The focus of this aforementioned Water Quality and Resource Management Issues Workshop was to identify national and international priority water research issues with which LLNL may align their research efforts and contribute to resolving these needs. LLNL staff researched various sectors to delineate the key water issues associated with each. This preliminary water issue research included diverse entities such as international water agencies, federal and state agencies, industry, non-governmental agencies, and private organizations. The key (identified) water issues across these sectors were presented to workshop attendees and used during workshop debates and sessions. However, the key water issues of federally recognized Native American tribes remained less understood, resulting in a workshop proposal for additional research and LLNL potentially hosting a dialog with representatives of these tribes.

Federally recognized Native American tribes have a unique government-togovernment relationship with the United States (U.S.) government, in contrast to other sectors researched for the workshop. Within the U.S., the number of federally recognized tribes currently stands at 562 and, in addition to this large number of tribes, much diversity across these tribes exists. For the purposes of this preliminary research and report, it was necessary to confine the analysis to a smaller geographic area, yet still represent the diversity of tribes and context within which tribal water issues arise. The state of California provides this opportunity. California has 106 federally recognized tribes. California is diverse in its geography, environment, demographics, and economic bases; California tribes demonstrate similar diversity. Additionally, no central repository of national or state tribal water issues exists and information must be aggregated, in general, tribe by tribe. This presents research challenges and, for this report, these were overcome by developing a method to essentially "sub-sample" the 106 federally recognized tribes in the state, while making every effort to maintain a sub-sample that broadly represents all of the 106 tribes.

In an effort to develop an equitable and appropriate method with which to identify this set of representative tribes, multiple entities were contacted for guidance. Consultation with the Bureau of Indian Affairs (BIA), Environmental Protection Agency (EPA), Indian Health Services (IHS), U.S. Department of Agriculture (USDA), Bureau of Reclamation (BOR) and Tribal Environmental Directors, provided key information and recommendations to guide the research process. It is hoped that an appropriate representation of the diversity of tribes across the 
state has been achieved; this includes an adequate representation of similarities and differences between Californian tribes on key water research issues (and the same between regions). This research occurred over a limited time period (i.e., three months) and given a general concern that this may not be sufficient, any information and conclusions in this report should be viewed with this in mind. Finally, it is hoped that this research allows for an (enhanced) informed capacity to better propose further dialog between tribes and LLNL to continue to exchange water research perspectives and define potential research collaborations.

\section{Research Constraints}

Researching the key water issues and the context within which these arise for California tribes is neither a straightforward nor an easy task. The number of California federally recognized tribes is large (i.e., 106) and these tribes are quite diverse, resulting in a challenging information gathering process. Also, information on tribes is not centrally or, in general, formally organized nor available. In large part, information must be gathered from interviews with many key contacts both within agencies and across tribes. Given these broad challenges for researching tribes, a number of additional difficulties were encountered while carrying out this research including:

- The perception that this proposed research could not be appropriately carried out within the allocated timeframe. Specifically, the BIA and other environmental organizations strongly communicated that the objectives of this research were not possible to complete within three months (i.e., the time allocated for this project);

o The challenge in developing an equitable and appropriate method with which to identify a smaller, yet representative, set of California federally recognized tribes to contact, interview (if possible and granted), and to invite for further dialog with LLNL, given the high diversity and differences between tribes (i.e., a method perceived by all as equitable and appropriate);

- Sensitivities and challenges in contacting and requesting information with tribes that are currently involved in water rights litigation;

- The lack of a straightforward process to identify the appropriate and key contacts within some federal agencies that work with Native American tribes, specifically on water issues;

$\circ \quad$ The unique structure of government extant within each tribe making the initial identification of the appropriate contact difficult;

- Challenges or long delays to information disclosure with a number of tribes that can not release any tribal information without the Tribal Chairman or Tribal Council's approval;

- Challenges to information disclosure with individual EPA Program officers that felt it inappropriate to provide tribal related information or recommend, due to rules of confidentiality or other various reasons, any tribes as candidates for further contact or inclusion in further dialog; 
- A lack of clarity in delineating the manner in which federal agencies provide their services to tribes without crossing another agency's jurisdiction;

- A often needed capacity to provide an answer to the question from tribal staff, "How can LLNL work with our tribe?" that resonates with tribe values (across diverse tribes) and prior to tribes feeling comfortable in releasing information.

\section{Methodology}

As noted previously, over one hundred federally recognized California tribal nations exist and these tribes are quite diverse. Information about these tribes and their water issues is also difficult to obtain. Given the limited time in which to carry out this project and the complexity in researching tribal water issues (see research constraints), it became necessary to develop a method to limit the number of tribes contacted and/or researched. However, it remained important to accomplish this in a manner that would prove representative of the remaining tribes. With the use of this method, a total of 18 tribes were selected (i.e., 6 from each of three regions within California) to represent the 106 federally recognized California tribes; this core set of 18 tribes was subsequently researched, as possible, in detail.

Interviews with key contacts at multiple federal agencies (see following list) provided a means to make a best effort in developing an equitable and appropriate method for selecting these representative tribes and to delineate three categories within which to represent tribal nations' water issues. Interviews with the following federal agencies, tribal officers, and non-profit organizations proved instrumental in developing this selection method:

- Bureau of Indian Affairs - Water Resource Office, Pacific Regional Office;

- Environmental Protection Agency- Water Division \& Indian Programs Office, Region IV;

- Indian Health Services - Office of Environmental Health Services;

- Bureau of Reclamation - Native American Affairs Office;

○ U.S. Department of Agriculture - Natural Resources Conservation Services;

- California State Water Resources Control Board;

- Council of Energy Resources Tribes;

- National Tribal Environmental Council;

- Native American Environmental Protection Consortium;

- Many Native American Tribal Environmental Staff.

Interviews with key staff at these various agencies resulted in recommendations of tribes that fit geographic regions and categories that characterize the level of water research and management efforts by a tribe. It also resulted in recommendations on tribes with which would provide a fairly good representation 
of other tribes throughout the state. 
Figure 1. Map of U.S. Environmental Protection Agency and Bureau of Indian Affairs regions for federally recognized California tribes.

\section{EPA Map of Federally Recognized Tribes}

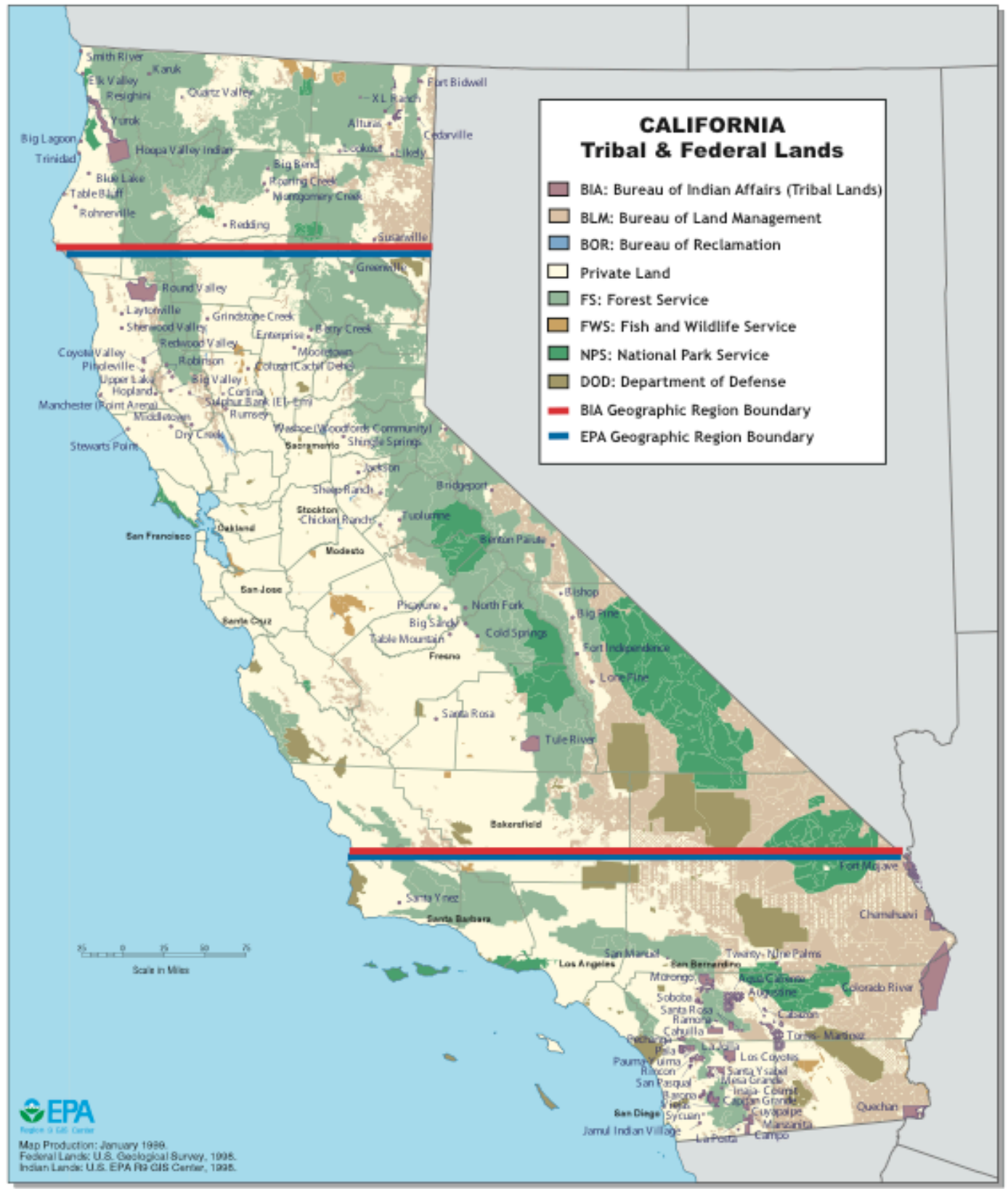




\section{Geographic Regions}

In California, the EPA and BIA have designated three jurisdictional regions within the state (Figure 1). Although administratively defined, these regions may offer some broad factors that may impact tribes within each region similarly. These factors may include climate, water availability and source, land use types, and economic infrastructure. To identify whether regional patterns of tribal technical water issues exist, these three regions were used as one category within which to select tribes for further research. These regions include:

$\circ \quad$ Northern Region: includes 18 federally recognized tribes and extends from the Oregon border to just below the Redding area. Includes communities such as Capetown, Red Bluff, and Herlong.

- Central Region: includes $\mathbf{5 5}$ federally recognized tribes and extends from just below the Redding area to just below the Bakersfield area. Includes communities such as Grover City, Tehachapi, and Barstow.

- Southern Region: includes $\mathbf{3 3}$ federally recognized tribes and extends from just below the Bakersfield area to the border of Mexico. Includes communities such as Santa Barbara, Los Angeles, San Bernardino, and San Diego.

Although this present research is constrained by time and funding, any future research undertaken may want to assess the effects of dividing the state into regions not jurisdictionally based, but rather based on specific variables (e.g., climate, geography/land use, proximity to water sources, etc.) to determine if these alternative regional definitions make a difference in conclusions on tribes' water research issues and delineating patterns of these across diverse tribes. For this report, it is assumed that some similar factors are encountered by tribes inhabiting the same jurisdictional region that may affect their prioritization of water issues.

\section{Categories of Water Programs}

Three categories of water programs were defined for this research in an effort to broadly characterize the type and level of technical water research and management efforts ongoing with each tribe. This was a key step in ensuring that selected tribes for further research were representative of tribes across the state and within the three identified regions. These three categories include tribes with a:

$\circ$ Category A: 1) well established water program or department and 2) relatively high degree of identification and understanding of their water issues.

Tribes in this category have a relatively well established water program or department and have been working on water issues for the relatively long period of time relative to other tribes within their geographic region. These tribes typically have received multiple water grants from federal agencies to resolve or enhance their water issues and further their water research. 
○ Category B: 1) water program or department present and 2) relatively moderate degree of identification and understanding of their water issues.

Tribes in this category have recently started a water program or department. These tribes typically have received some grants from federal agencies, yet fewer than the former category.

○ Category C: 1) no established water program or department and 2) newly formed or forming identification and understanding of their water issues.

Most tribes in this category are without a water program or department and are fairly new at identifying or working on their water issues.

Number of Tribes per Region and Category

For each of the three regions, two tribes were selected to represent that region for each water program category. This selection method results in six tribes per region identified, with a total of 18 tribes that are intended to be representative of tribes across the state. The next steps in this process involved researching this set of tribes in more detail to understand regional tribal water issues, patterns of water research needs across tribes, and the context within which these arise.

\section{Selection Method Results: Representative Tribes}

In a "best effort" to define a smaller set of tribes across the state that may represent the diversity of all federally recognized California tribes, multiple resources were used. This included a literature search for information relevant to California tribes, interviews with multiple resources, and consultation with staff at multiple federal agencies that work directly with tribes in their jurisdiction regarding water issues. This information and/or recommendations led to a preliminarily placement of tribes into the aforementioned regions and water program categories; any future research may want to further assess whether this preliminary assessment proved appropriate. Tribal staff involved with water issues, from each of these identified and/or recommended tribes, were subsequently interviewed to gather more detailed information. Appendix A provides detailed information regarding the technical water issues for each tribe. Appendix $B$ describes the recommendations received from various resources and agencies.

The fact that each tribe is a sovereign nation with a unique structure of government impacted the next step of contacting tribal staff at each identified tribe. The varying tribal organization presented initial challenges in the identification of the appropriate tribal contact. Multiple roles and titles exist with which refer to a tribal staff member responsible for managing water related issues. Although not an exhaustive list, these titles include: Natural Resource Director, Water Specialist, Tribal Public Utility Department General Manager, Environmental Director, and Tribal Water Resources Coordinator. This varying tribal organization, tribal water program stage of development, and staff titles should be kept in mind for any future research purposes. 
The following tribes from each region were researched in this manner:

- Northern Region Tribes:

Hoopa Valley Indian Reservation

Yurok Tribe

Trinidad Rancheria

Karuk Tribe of California

Pit River Tribe

Bear River Band of the Rohnerville Rancheria

○ Central Region Tribes:

Round Valley Reservation ${ }^{1}$

Bishop Reservation

Tule River Reservation ${ }^{1}$

Jackson Rancheria Band of Mewuk Indians'

Benton Paiute Reservation ${ }^{1}$

Coyote Valley Band of Pomo Indians

- Southern Region Tribes:

Colorado River Indian Tribes

Pechanga Band of Mission Indians

Agua Caliente Band of Chuilla Indians

La Jolla Band of Luiseño Indians

Los Coyotes Band of Mission Indians

Santa Ysabel Band of Mission Indians ${ }^{2}$

${ }^{1}$ This tribe could not release any tribal information for this research and report prior to approval by the Tribal Chairperson or the Tribal Council.

${ }^{2}$ This tribe could not be contacted to participate in this research and report.

\section{Feedback on Selection Method}

Feedback on the selection method developed and used for this research was sought during the interviews with tribal staff, federal agencies, and private organizations. This additional step was taken in an effort to better ensure that this method resulted in a set of representative tribes and that the method was deemed by diverse entities as appropriate and equitable. Many comments were received and the following examples, from a wide range of agencies and staff, provide a relatively good sampling of this feedback:

- Dr. Chuck Patterson, Environmental Director, La Jolla Band of Luiseño Indians: "I think that formula would be the best way...It would get time consuming to invite all tribes and hard to complete the agenda."

- Ron Thompson, Director of Water Programs, National Tribal Environmental Council: "It's a good approach for the vast variety of tribes."

- Allen Spoonhunter, Environmental Manager, Bishop Reservation: “It's a good formula."

○ Paul Young, Director of Environmental Health Services: “Normally that's 
how it was done."

- Bessie Lee, EPA: "Team up your meeting with another existing annual tribal meeting to insure tribes' participation; possibly LLNL could have a break out session that piggy-backs the main meeting or conference."

- Frank Fryman, California BIA: "It sounds pretty good."

\section{RESEARCH RESULtS}

The following information and conclusions result from contacts, interviews, and information aggregation from tribal water directors, tribal enrollment officers, tribal administrators, the U.S. Census 2000, and Tiller's Guide to Indian Country. Out of the 18 selected tribes, four tribes could not release any tribal information until it was approved by the Tribal Chairman or Tribal Council, depending on the tribe's system of government (note: this project's limited scope was not sufficient to formally request and attain approval). The four tribes that did not respond include the: Round Valley Reservation, Tule River, Jackson Rancheria Band of Mewuk Indians, and the Benton Pauite Reservation. Also, the Santa Ysabel Band of Mission Indians water personnel could not be reached. This resulted in underreporting of information for the Central Region tribes. Future research may include formally approaching (i.e., a letter from LLNL requesting approval to interview and receive tribal water issues information) the Tribal Chairpersons or Councils for these four tribes in the Central region and receive approval to interview their water staff.

The information gleaned from the relatively more detailed interviews of tribal staff from the remaining 13 tribes is provided below. It remains to be seen if this information is appropriately representative of all federally recognized tribes across the regions and the state, although some similarities may be discerned.

\section{Technical Water Research Issues}

As the following tables demonstrate, the aggregated results from interviews with tribal staff at the selected set of representative tribes resulted in identifying that the key technical water research issues for California tribes are primarily related to water quality and infrastructure issues, yet also involve information management, analytical laboratory, water scarcity/drought, and irrigation efficiency (Table1) issues or agendas. 
Table 1. Technical water issues of California tribal nations, with results based on representative tribes from each of the three regions in the state.

\begin{tabular}{|l|c|}
\hline Category of Water Issue & $\begin{array}{c}\text { \# of Times Issue } \\
\text { Identified by Tribes }\end{array}$ \\
\hline \hline Water Quality & $\mathbf{2 3}$ \\
Surface Water Contamination & $(7)$ \\
Bacteria Contamination & $(5)$ \\
Establish Standards/Water Plan & $(3)$ \\
Drinking Water Contamination & $(3)$ \\
Groundwater Contamination & $(3)$ \\
Source Water Protection & $(1)$ \\
Ocean Monitoring & $(1)$ \\
\hline Infrastructure & $\mathbf{8}$ \\
\hline Information Management & $\mathbf{2}$ \\
\hline Analytical Laboratory & $\mathbf{2}$ \\
\hline Water Scarcity/Drought & $\mathbf{1}$ \\
\hline Irrigation Efficiency & $\mathbf{1}$ \\
\hline
\end{tabular}

In comparing the priority statewide technical water issues of tribes (i.e., identified from the representative set of state tribes interviewed) to those priority issues within each of the three regions, water quality and infrastructure issues remain at the forefront of priorities. Table 2 provides a detailed list of the regional water issues identified within interviews with tribes representing the Northern, Central, and Southern regions. Note that the Central Region remains underrepresented in this analysis due to the inability to get tribal permissions for information release in time for this report. 
Table 2. Regional technical water issues of California tribal nations, with results based on representative tribes from each of the three regions in the state.

\begin{tabular}{|c|c|c|c|c|c|}
\hline Northern Region & & Central Region & & Southern Region & \\
\hline $\begin{array}{l}\text { Water Quality: Surface } \\
\text { Water Contamination }\end{array}$ & 5 & $\begin{array}{l}\text { Water Quality: Surface } \\
\text { Water Contamination }\end{array}$ & 1 & $\begin{array}{l}\text { Water Quality: } \\
\text { Drinking Water } \\
\text { Contamination }\end{array}$ & 3 \\
\hline $\begin{array}{l}\text { Infrastructure: } \\
\text { Wastewater Treatment }\end{array}$ & 4 & $\begin{array}{l}\text { Infrastructure: } \\
\text { Wastewater Treatment }\end{array}$ & 1 & $\begin{array}{l}\text { Water Quality: } \\
\text { Bacteria } \\
\text { Contamination }\end{array}$ & 2 \\
\hline $\begin{array}{l}\text { Water Quality: } \\
\text { Bacteria } \\
\text { Contamination }\end{array}$ & 2 & $\begin{array}{l}\text { Water Quality: } \\
\text { Bacteria } \\
\text { Contamination }\end{array}$ & 1 & $\begin{array}{l}\text { Water Quality: } \\
\text { Surface Water } \\
\text { Contamination }\end{array}$ & 1 \\
\hline $\begin{array}{l}\text { Water Quality: } \\
\text { Establish } \\
\text { Standards/Water Plan }\end{array}$ & 2 & $\begin{array}{l}\text { Infrastructure: } \\
\text { Enlarge/Leaks, } \\
\text { Improve Water } \\
\text { Storage Tanks }\end{array}$ & 1 & $\begin{array}{l}\text { Water Quality: } \\
\text { Groundwater } \\
\text { Agriculture Pesticide } \\
\text { Contamination }\end{array}$ & 1 \\
\hline $\begin{array}{l}\text { Water Quality: } \\
\text { Groundwater } \\
\text { Contamination, } \\
\mathrm{Mg} / \mathrm{Fe} / \mathrm{Na}\end{array}$ & 2 & $\begin{array}{l}\text { Information } \\
\text { Management: Data } \\
\text { Use/Maintenance }\end{array}$ & 1 & $\begin{array}{l}\text { Water Quality: } \\
\text { Establish } \\
\text { Standards/Water Plan }\end{array}$ & 1 \\
\hline $\begin{array}{l}\text { Infrastructure: } \\
\text { Building New System }\end{array}$ & 1 & Analytical Laboratory & 1 & $\begin{array}{l}\text { Water Quality: Source } \\
\text { Water Protection }\end{array}$ & 1 \\
\hline \multirow[t]{5}{*}{$\begin{array}{l}\text { Water Quality: Ocean } \\
\text { Monitoring System }\end{array}$} & \multirow[t]{5}{*}{1} & & & $\begin{array}{l}\text { Water } \\
\text { Scarcity/Drought }\end{array}$ & 1 \\
\hline & & & & Analytical Laboratory & 1 \\
\hline & & & & $\begin{array}{l}\text { Information } \\
\text { Management: Data } \\
\text { Use/Maintenance }\end{array}$ & 1 \\
\hline & & & & $\begin{array}{l}\text { Infrastructure: } \\
\text { Enlarge/Leaks, } \\
\text { Improve Water } \\
\text { Storage Tanks }\end{array}$ & 1 \\
\hline & & & & Irrigation Efficiency & 1 \\
\hline
\end{tabular}

Demographics and Context

In addition to identifying the tribes' priority technical water research issues, the context within which these issues arise is important to understand. As a result, research for this report included aggregating information on the demographics of the representative tribes across the state; this included information describing tribal populations, land use, and economic development.

The size of tribes across the state varies widely, as represented by the 18 tribes researched in more detail. Some tribes have just a handful of members, yet are federally recognized, while other tribes have thousands of members. While it is difficult to speculate on the impact of tribal membership size for water issues, it is clearly possible that size may be an important variable to whether or not water issues are problematic, the degree of water infrastructure required, the staff or 
capacity to work on water issues, and so forth. Table 3 describes this wide range of tribal population.

Table 3. Population for each of the 18 tribes researched.

\begin{tabular}{|r|c|}
\hline $\begin{array}{c}\text { Number of } \\
\text { Tribal Members }\end{array}$ & $\begin{array}{c}\text { \# of Tribes } \\
\text { with this } \\
\text { population }\end{array}$ \\
\hline \hline $4,000-4,999$ & 1 \\
\hline $3,000-3,999$ & 2 \\
\hline $2,000-2,999$ & 3 \\
\hline $1,000-1,999$ & 1 \\
\hline $900-999$ & 0 \\
\hline $800-899$ & 1 \\
\hline $700-799$ & 1 \\
\hline $600-699$ & 0 \\
\hline $500-599$ & 0 \\
\hline $400-499$ & 1 \\
\hline $300-399$ & 2 \\
\hline $200-299$ & 2 \\
\hline $100-199$ & 1 \\
\hline $0-99$ & 3 \\
\hline &
\end{tabular}

Land ownership potentially provides information regarding tribal water use and the origin of technical water issues. For example, a large reservation may mean that the economic base is tied to land use and this land use may be dependent on water availability, quality, and other related factors. Or conversely, for a small reservation that may yet have water ownership (but not much land), it's tribal economic or cultural stability may rely heavily on this water resource.

The quantity of land owned by the tribes researched for this report was surprisingly small. Table 4 describes this land ownership. Half of the tribes owned less than 15 square miles (39 sq km [9,600 ac or 3885 ha]); only one or two tribes had a relatively larger land ownership, which skewed the average to double that of a typical tribe in this report. However, even the largest land area owned by a tribe remains small. This limited land constrains the tribes capacity to use the land for an economic base, such as large-scale agriculture. It also constrains the need for irrigation water. This seemed to potentially (i.e., anecdotally) determine economic development opportunities available to the tribes. 
Table 4. Trust land owned by each of the 18 tribes researched.

\begin{tabular}{|l|l|}
\hline \multicolumn{2}{|c|}{ Tribal Land Ownership } \\
\hline \hline Median & 15 sq miles (39 sq km) \\
\hline Average & 31 sq miles (80 sq km) \\
\hline Range & $\begin{array}{l}.07 \text { to } 142 \text { sq miles (0.18 to } 368 \mathrm{sq} \\
\mathrm{km})\end{array}$ \\
\hline
\end{tabular}

For example, this research assessed the extent of agricultural activities occurring on these tribal lands. Four categories of tribal land use were determined including: no farming, small family gardens for subsistence, large-scale farming as a source of generating tribal revenue, and tribes who preferred not to release tribal information without a formal request (i.e., LLNL letter of inquiry to the tribal chairperson or council). Table 5 describes the manner in which these tribes fit into these categories.

Table 5. Description of land use by each of the 18 tribes researched.

\begin{tabular}{|l|c|}
\hline \multicolumn{1}{|c|}{ Agricultural Land Use } & \# of Tribes \\
\hline \hline No farming & 9 \\
\hline Only family farming & 5 \\
\hline Large-scale farming & 1 \\
\hline No information & 3 \\
\hline
\end{tabular}

Finally, the major sources of revenue for tribes were examined with the objective of understanding the relation of this economic development to technical water research issues or current and future water needs. A diversity of economic development activities and revenue sources was found across the tribes, with gaming or casinos as the most predominant revenue source for most tribes. However, despite this predominant source, the underlying pattern of economic development was one that highlighted the fact that each tribe tended to rely on a diverse set of revenue sources dependent on the resources available to the tribe. As a result, Table 6 demonstrates a wide array of revenue generating activities and highlights the general type of these activities (i.e., generally service oriented rather than agricultural or industrial). 
Table 6. Sources of revenue for 18 California tribes, with results based on representative tribes from each of the three regions in the state.

\begin{tabular}{|l|c|}
\hline Category of Revenue Base & \# of Tribes \\
\hline \hline Gaming/Casino & 10 \\
\hline Timber Sales & 4 \\
\hline Campground / Hiking Trails & 4 \\
\hline Federal Support & 2 \\
\hline Service Stations & 1 \\
\hline Trailer Parks & 1 \\
\hline Commercial Fisheries & 1 \\
\hline Water Parks & 1 \\
\hline Marine Parks & 1 \\
\hline Airports & 1 \\
\hline Plastics Manufacture & 1 \\
\hline Agricultural Sales & 1 \\
\hline
\end{tabular}

With results that demonstrate a largely service/tourism oriented or natural resource use (e.g., fisheries) economic base, it is not surprising that the key water issues identified by these tribes were typically water quality issues (and mainly contamination from outside sources or infrastructure-related issues) rather than issues associated with agriculture.

\section{Proposed Roundtable Format}

LLNL staff that participated in the Water Quality and Resource Management Workshop in January 2003, part of the LLNL Water Initiative, expressed an interest in LLNL hosting further dialogs or discussions with tribes to better understand tribal water research priority issues and to understand any arenas for collaboration. At the time of the first proposal, it was unclear what format may facilitate meaningful discussion. Based on information aggregated from contacting individual tribes, staff at federal agencies, and other entities, it is recommended that one round table (i.e., rather than a series of round tables, one for each region). This albeit preliminary and limited research into the priority water issues for federally recognized tribes in California, seems to point to tribes identifying water quality and infrastructure issues above other water research areas as key. These tribes also seem to share many sub-issues within these broad categories as well. The regions, despite differences in geography, regional climate, tribal membership size, land ownership, economic base, and other variables, did not differ enough in their primary water issues to support a regional series of round tables. Therefore, the following recommendations are proposed for a round table, if held: 


\section{RECOMMENDATIONS}

$\circ \quad$ Make the goals of the Water Quality and Resource Management Workshop (and LLNL Water Initiative) and reasons behind interest in forging technical water research collaborations with California tribes transparent (i.e., enhance mutual understanding and trust);

- Ensure an opportunity for exchange of information and relationshipbuilding (i.e., enhance trust);

- Address tribal technical water issues and LLNL water research and technology resources;

- Discuss the manner in which tribal nations and LLNL may partner on research issues;

- Schedule a subsequent meeting, should both entities jointly agree to further the discussion on water research collaborations.

- Plan on a discussion or dialog over more than one meeting. A history of tribal distrust for the Department of Energy exists, and by extension, this may apply to national laboratories.

\section{Conclusions}

The information aggregated from conducting both broad research of federally recognized California tribes and a more detailed research into a representative set of tribes within regions of the state demonstrate important technical water issues for tribes within California. LLNL has the opportunity to understand and include the technical water research priorities of another sector in the nation (i.e., tribes) to aid in efforts to better align LLNL water research and development with areas with which are key to the nation and in which LLNL may contribute. A dialog with tribal staff from representative tribes across the state may engender a greater understanding, a more refined LLNL water research agenda, and fruitful collaborations.

- A California Tribal Nations Technical Water Research round table may add an enhanced perspective to LLNL's Water Initiative;

- Discussions may lead to collaborations and partnerships in researching water issues;

- Federal funding may support partnerships between California tribes and LLNL for water research efforts;

- Water and Energy issues are typically linked for tribes, representing a wider breadth of potential collaborations;

- This project has the potential to be applied across the U.S. to the remaining Native American tribes. 


\section{REFERENCES}

Lawrence Livermore National Laboratory. 2003. Water Quality and Resource Management Issues, Workshop Report. Facilitated by National Water Research Institute. January 28-30, 2003.

Tiller, V.E. 1996. Tiller's Guide to Indian Country: Economic Profiles of American Reservations. BowArrow Publishing Company. Albuquerque, New Mexico.

U.S. Census 2000. 
Appendix A: Selected Tribes, Regions \& Water Programs

Review of Water Program Category Definitions

Category A: 1) well established water program or department and 2) relatively high degree of identification and understanding of their water issues.

Tribes in this category have a relatively well established water program or department and have been working on water issues for the relatively long period of time relative to other tribes within their geographic region. These tribes typically have received multiple water grants from federal agencies to resolve or enhance their water issues and further their water research.

Category $B: 1$ ) water program or department present and 2) relatively moderate degree of identification and understanding of their water issues.

Tribes in this category have recently started a water program or department. These tribes typically have received some grants from federal agencies, yet fewer than the former category.

Category C: 1) no established water program or department and 2) newly formed or forming identification and understanding of their water issues.

Most tribes in this category are without a water program or department and are fairly new at identifying or working on their water issues. 


\section{Category A.}

1. Northern Region

\section{HOPPA VALLEY INDIAN RESERVATION}

\section{YUROK TRIBE}

- EPA identifies both tribes to have well-established water programs relative to many tribes within the Northern region;

- EPA also identifies them as more advanced in water related research and activities;

- Received Performance Partnership Grants to support their water programs efforts. ${ }^{1}$ Note: multiple grants comprise this Performance Partnership Grant, includes a specific water grant.

\section{Central Region}

\section{ROUND VALLEY RESERVATION}

- EPA identified as more technologically advanced with water related efforts relative to other tribes in this region. ${ }^{2}$

\section{BISHOP RESERVATION}

- The National Tribal Environmental Council identifies this tribe as one with the most advances water system in the region; ${ }^{3}$

- The tribe currently has four EPA water quality grants, as well as a Bureau of Indian Affairs (BIA) Water Resource Management and Planning grant; ${ }^{4}$

- Bishop enacted a tribal water code and is in the initial phase of working with Indian Health Services for long term planning of surface and ground water consumptive use.

\section{Southern Region}

\section{COLORADO RIVER INDIAN TRIBES (CRIT)}

- Established water department since 1993 and maintains various water programs and projects; ${ }^{5}$

○ Very advance water system for their large agricultural farms and casino. ${ }^{6}$

\section{PECHANGA BAND OF MISION INDIANS}

$\bigcirc$ Relatively more sophisticated water technology system than neighboring tribes;

○ Received EPA, BIA, and State water grants; ${ }^{7}$

- Recommended as a good fit for this category; ${ }^{8}$

$\circ$ Their water department was one of the first departments created. ${ }^{9}$ 


\section{Category B.}

1. Northern Region

\section{TRINIDAD RANCHERIA}

- Established program for the last three years with hardworking staff, although program is not as established as the Hoopa and Yurok Tribes. ${ }^{10}$

KARUK TRIBE OF CALIFORNIA

$\bigcirc$ Received two EPA grants, one grant with the Indian Health Services, and submitted the Clean Water Quality Act, Section 305(b) Report to the State; ${ }^{11}$

- Recommended as a good fit for this category in comparison to other tribes in the region. ${ }^{12}$

2. Central Region

\section{TULE RIVER RESERVATION}

$\bigcirc \quad$ Working on their water issues for the past five years. ${ }^{13}$

JACKSON RANCHERIA BAND OF MEWUK INDIANS

- National Tribal Environmental Council recommends the Jackson Rancheria for this middle level of the three. ${ }^{14}$

\section{Southern Region}

\section{AGUA CALIENTE BAND OF CHAUILLA INDIANS}

○ Has through understanding of their water issues and are technologically aware $;^{15}$

- Has an Environmental Resources department;

- Received a non-General Assistance Program (GAP) grant, and according to the EPA list of tribes have a water quality grant.

\section{LAJOLLA BAND OF LUISENO INDIANS}

- Operates a Water Department and a Natural Resources Department (15 year operational history), resulting the tribe's award of EPA GAP, Section 106 Water Pollution Center, Section 316 Non-Point, Wet-land grants, and two BIA grants. ${ }^{16}$ 


\section{Category C.}

1. Northern Region

PIT RIVER TRIBE

- Currently developing water quality standards and received a few grants. ${ }^{17}$

$\circ$ EPA identifies this tribe as fairly new to water issues. ${ }^{18}$

BEAR RIVER BAND OF ROHNERVILLE RANCHERIA

$\circ$ EPA identifies this tribe as fairly new to water issues. ${ }^{19}$

2. Central Region

\section{BENTON PAIUTE RESERVATION}

- According to the tribe's spokesperson, they do not have an establish Natural Resources Department, nor a water program, and prefers to offer no tribal information by phone.

COYOTE VALLEY BAND OF POMO INDIANS

○ USDA identifies this tribe as in their initial phase of creating an Environmental Office and a Water Program. ${ }^{20}$

\section{Southern Region}

\section{LOS COYOTES BAND OF MISSION INDIANS}

- Less established water department relative to other area tribes. ${ }^{21}$

\section{SANT YSABEL BAND OF MISSION}

○ Water program is in early stages, due to a new water administrator with limited experience in water technology and an entire new tribal administration. $^{22}$ 
${ }^{1}$ Personal communication with T. Whillhite, U.S. EPA, Indian Programs Office, Northern California Project Officer, Yrek, California, June 30, 2003.

${ }^{2}$ Personal communication with C. Grillant, U.S. EPA, Water Division Project Officer, San Francisco, California, July 1, 2003.

${ }^{3}$ Personal communication with R. Thompson, National Tribal Environmental Council, Director of Water Programs, Albuquerque, New Mexico, July 14, 2003.

${ }^{4}$ Personal communication with A. Spoonhunter, Bishop Tribe, Tribal Environmental Manager, Bishop, California, July 14, 2003.

${ }^{5}$ Personal communication with G. Handson, CRIT Water Resource Director, Parker, Arizona, July 9, 2003.

${ }^{6}$ Personal communication with L. Marquez, BIA, Land and Water Resources, Phoenix, Arizona, July 12, 2003.

${ }^{7}$ Personal communication with J. Fletcher, U.S. EPA, Water Division, Southern California Water Quality Pollution Control Officer, July 24, 2003.

${ }^{8}$ Personal communication with R. Thompson, National Tribal Environmental Council, Director of Water Programs, Albuquerque, New Mexico, July 14, 2003.

${ }^{9}$ Personal communication with R. Pico, Lawrence Livermore National Laboratory, Senior Supervisor, Electronic Engineering and Pechanga Tribal Member, July 11, 2003.

${ }^{10}$ Personal communication with T. Whillhite, U.S. EPA, Indian Programs Office, Northern California Project Officer, San Francisco, California, July 14, 2003.

${ }^{11}$ Personal communication with S. Quinn, Karuk Tribe's Water Resource Coordinator, Orleans, California, July 14, 2003.

${ }^{12}$ Personal communication with T. Whillhite, U.S. EPA, Indian Programs Office, Northern California Project Officer, San Francisco, California, July 14, 2003.

${ }^{13}$ Personal communication with D. Schultz, Tule River Water Resource Director, Porterville, California, July 9, 2003.

${ }^{14}$ Personal communication with R. Thompson, National Tribal Environmental Council, Director of Water Programs, Albuquerque, New Mexico, July 14, 2003.

${ }^{15}$ Personal communication with B. Lee, U.S. EPA, Indian Programs Office, Southern California Project Officer, San Francisco, California, July 24, 2003.

${ }^{16}$ Personal communication with C. Patterson, La Jolla Band of Luiseno Indians' Environmental Director, Pauma Valley, California, July 11, 2003.

${ }^{17}$ Personal communication with C. Pirosko, Pit River Tribe, Water Resource Coordinator, Burney, California, July 24, 2003.

${ }^{18}$ Personal communication with T. Whillhite, U.S. EPA, Indian Programs Office, Northern California Project Officer, San Francisco, California, July 14, 2003.

${ }^{19}$ Personal communication with T. Whillhite, U.S. EPA, Indian Programs Office, Northern California Project Officer, San Francisco, California, July 14, 2003.

${ }^{20}$ Personal communication with R. Rogers, United States Department of Agriculture, Natural Resources Conservation Services, American Indian Liaison, Greenville, California July 29, 2003.

${ }^{21}$ Personal communication with J. Flitcher, U.S. EPA, Southern California Water Quality Pollution Control Officer, San Diego Boarder Office, California, July 24, 2003.

${ }^{22}$ Personal communication with B. Lee, U.S. EPA, Indian Programs Office, Southern California Project Officer, San Francisco, California, July 24, 2003. 
Appendix B: List of California Tribes and Key Contacts

\section{Federally recognized California tribes}

Agua Caliente Band of Cahuilla Indians Richard M. Milanovich (Chairman) 600 East Tahquitz Canyon Way Palm Springs, CA 92262

(760) 325-3400

Fax: 325-4954
Tyme Maidu Tribe-Berry Creek Reservation Jim Edwards (Chairman)

5 Tyme Way

Oroville, CA 95966

(530) 534-3859

Fax: 534-1151

Big Lagoon Rancheria

Virgil Moorehead (Chairman)

Yurok and Tolowa

Post Office Drawer 3060

Trinidad, CA 95570

(707) 826-2079

Fax: 826-0495

Big Pine Band of Owens Valley Jessica Bacoch (Chairwomen)

Paiute-Shoshone

Post Office Box 700

Big Pine, CA 93513

(760) 938-2003

Fax: 938-2942

\section{Barona Rancheria}

Kumeyaay (Diegueño)

Clifford LaChappa (Chairman)

1095 Barona Road

Lakeside, CA 92040

(619) 443-6612

Fax: 443-0681
Big Sandy Rancheria Connie Lewis (Chairwoman) Western Mono (Monache) PO Box 337

Auberry, CA 93602

(559) 855-2103

Fax: 855-4640 


\section{Federally recognized California tribes}

Utu Utu Gwaitu Paiute Tribe of the Benton

Paiute Reservation

Rose Marie Salque (Chairwoman)

567 Yellow Jacket

Benton, CA 93512

(760) 933-2321

Fax: 933-2412

Bishop Reservation

Dough Vega (Chairman)

Paiute-Shoshone

Post Office Box 548

50 Tu Su Lane

Bishop, CA 93515

(760) 873-3584

Fax: 873-4143

Blue Lake Rancheria

Claudia Brundin (Chairwoman)

Wiyok, Yurok, Hupa

Post Office Box 428

Blue Lake, CA 95525

(707) 668-5101

Fax: 668-4272

Bridgeport Indian Colony

Jerald Sam (Chairman)

Paiute

Post Office Box 37

Bridgeport, CA 93517

(760) 932-7083

Fax: $932-7846$
Big Valley Rancheria

Anthony Jake (Chairman)

Pomo and Pit River

2726 Mission Rancheria Road

Lakeport, CA 95453

(707) 263-3924

Fax: 263-3977

Cahuilla Band of Mission Indian

Eugenia Nogales (Chairwoman)

Post Office Box 391760

Anza, CA 92539-1760

(909) 763-5549

Fax: 763-2808

Campo Band of Kumeyaay Indians

Ralf Goff (Chairman)

Kumeyaay (Diegueño)

36190 Church Road, Suite 1

Campo, CA 91906

(619) 478-9046

Fax: 478-5818

Cedarville Rancheria of Northern Paiute Indians

Virgina Lash (Chairwoman)

200 South Howard Street

Alturus, CA 96101

(530) 233-3969

Fax: 233-4776 


\section{Federally recognized California tribes}

Buena Vista Rancheria of Me-Wuk Indians

Donna W. Marie Potts

4650 Coal Mine Road

Ione, CA 95640

(209) 274-6512

Fax: 274-6514

Cabazon Band of Mission Indians

John James (Chairman)

Cahuilla

84-245 Indio Springs Pkwy.

Indio, CA 92203

(760) 342-2593

Fax: 342-7880

Cloverdale Rancheria of Pomo Indians

Patricia Hermosillo (Chaiwoman)

555 S. Cloverdale Blvd., \#1

Cloverdale, CA 95425

(707) 894-5775

Fax: 894-5727

Cold Springs Rancheria

Lonni Bill (Chairman)

Post Office Box 209

Tollhouse, CA 93667

(559) 855-5043

Fax: 855-4445
Chicken Ranch Rancheria

Lloyd Mathiensen (Chairman)

Miwok (Me-wuk)

Post Office Box 1159

Jamestown, CA 95327

(209) 984-4806

Fax: 984-5606

Chico Rancheria

Steve Santos (Chairman)

125 Mission Ranch Blvd.

Chico, CA 95926

(530) 899-8922

Fax: 899-8517

Ewilaapaayp Band of Kumeyaay Indians Harlan Pinto (Chairman

P. O. Box 2250

Alpine, CA 91903-2250

(619) 445-6315

Fax: 445-9126

Dry Creek Rancheria

Liz DeRoen (Chairwomen)

Pomo

Post Office Box 607

Geyserville, CA 95441

(707) 431-2388

Fax: 431-2615 


\section{Federally recognized California tribes}

Colusa Rancheria

Wayne R. Mitchum (Chairman)

Colusa, CA 95932

(530) 458-8231

Fax: (916) 458-3866

Cortina Rancheria

Elaine Patterson (Chairwoman)

Wintun

P.O. Box 1630

Williams, CA 95987

(530) 473-3274

Fax: 473-3301

Coyote Valley Band of Pomo Indians

Pricilla Hunter (Chairwomen)

Post Office Box 39

Redwood Valley, CA 95470-0039

(707) 485-8723

Fax: 485-1247
Elem Indian Colony of Pomo Indians

(Sulphur Bank Rancheria)

Delbert Thomas, Jr. (Chairman)

P.O. Box 989

Clearlake Oaks, CA 95423

(707) 998-4100

Fax: 998-1900

Elk Valley Rancheria

Dale A Miller (Chairman)

Tolowa

Post Office Box 1042

375 Wyentae Street

Crescent City, CA 95531

(707) 464-4680

Fax: 464-4519

Fort Bidwell Indian Community of Paiute Indians

Francis Benally (Chairwomen)

Post Office Box 129

Fort Bidwell, CA 96112

(530) 279-6310

Fax: 279-2233

Hopland Band of Pomo Indians

Sandra Sigala (Chairwoman)

Post Office Box 610

Hopland, CA 95449

(707) 744-1647

Fax: 744-9101

Fax: 878-2311 


\section{Federally recognized California tribes}

Greenville Rancheria of Maidu Indians

Lorie Jaimes (Chairwomen)

Post Office Box 279

Greenville, CA 95947

(530) 284-7990

Fax: 284-6612

Grindstone Indian Rancheria of Wintun-

Wailaki

Kenneth Swearinger (Chairman)

Post Office Box 63

Elk Creek, CA 95939

(530) 968-5365

Fax: 968-5366

Guidiville Rancheria

Marlene Sanchez (Chairwoman)

Post Office Box 339

Talmage, CA 95481

(707) 462-3682

Fax: 462-9183

Hoopa Valley Indian Reservation

Cllifford L. Marshall (Chairman)

Hupa

Post Office Box 1348

Hoopa, CA 95546

(530) 625-4211

Fax: 625-4594
Inaja \& Cosmit Band of Mission Indians Rebecca Maxcy-Osuna (Chairwoman) Ramona Band of Cahuilla Indians 1040 East Valley Parkway, Suite A Escondido, CA 92025

(760) 747-8581

Fax: 747-8568

Jackson (Rancheria) Band of Mewuk Indians

Margret Dalton (Chairwoman)

P.O. Box 1090

16070 Miwuk Drive

Jackson, CA 95642

(209) 223-1935

Fax: 223-5366

Jamul Band of Mission Indians

Kenneth Meza (Chairman)

Kumeyaay (Diegueño)

Post Office Box 612

Jamul, CA 91935

(619) 669-4785

Fax: 669-4817

Karuk Tribe of California

Alvis Johnson (Chairman)

Post Office Box 1016

Happy Camp, CA 96039

(530) 493-5305

Fax: 493-5322 


\section{Federally recognized California tribes}

La Jolla Band of Luiseño Indians

Wendy Schlater (Chairwoman)

22000 Highway 76

Pauma Valley, CA 92061

(760) 742-3771

Fax: 742-1704

La Posta Band of Mission Indians

Gwendolyn Parada (Chairwoman)

Kumeyaay (Diegueño)

P.O. Box 1120

Boulevard, CA 91905

(619) 478-2113

Fax: 478-2399

Laytonville Rancheria - Cahto Indian Tribe

Vernon Wilson (Chairman)

Post Office Box 1239

Laytonville, CA 95454

(707) 984-6197

Fax: 984-6201

Lone Pine Community of Paiute-Shoshone Indians

Racheal Joseph (Chairwoman)

P.O. Box 747

Lone Pine, CA 93545

(760) 876-1034

Fax: 876-8302
Lytton Rancheria

Margie Mejia (Chairwoman)

1250 Coddingtown Center, Suite 1

Santa Rosa, CA 95401

(707) 575-5917

Fax: 575-6974

\author{
Manchester/Point Arena Rancheria \\ Jose' Oropeza (Chairman) \\ Pomo \\ Post Office Box 623 \\ Point Arena, CA 95468 \\ (707) 882-2788
}

Fax: 882-3417

\author{
Manzanita Band of Mission Indian \\ Leroy Elliot (Chairman) \\ Kumeyaay (Diegueño) \\ Post Office Box 1302 \\ Boulevard, CA 91905 \\ 619-766-4930
}

Fax: 766-4957
Mesa Grande Band of Mission Indians Charlene Siford (Chirwoman)

Kumeyaay (Diegueño)

P.O. Box 270

Santa Ysabel, CA 92070

(760) 782-3818

Fax: 782-9029 


\section{Federally recognized California tribes}

Los Coyotes (Rancheria) Band of Mission

Indians

Catheryn Saubel (Chairwoman)

Cahuilla \& Cupeño

Post Office Box 189

Warner Springs, CA 92086

(760) 782-0711

Fax: 782-2701

Mooretown Rancheria of Maidu Indians

Gary Archuleta (Chairman)

1 Alverda Drive

Oroville, CA 95966

(530) 533-3625

Fax: 533-3680

Morongo Band of Mission Indians

Morice Lyons (Chairman)

Cahuilla, Serrano \& Cupeño

11581 Potrero Road

Banning, CA 92220-2965

(909) 849-4697

Fax: 849-4425

North Fork (Rancheria) Band of Mono Indians

Judy E. Fink (Chairwoman)

P.O. Box 929

North Fork, CA 93643-0929

(559) 877-2461

Fax: 877-2467
Middletown Rancheria of Pomo Indians Joe' Simon III. (Chairman)

Post Office Box 1035

Middletown, CA 95461

(707) $987-3670$

Fax: 987-9091
Paskenta Band of Nomlaki Indian Everitt Freeman (Chairman)

P.O. Box 398

Orland, CA 95963

(530) 865-2010

Fax: 865-1870
Pechanga Band of Mission Indians Mark Maccrro (Chairman)

Luiseño

Post Office Box 1477

Temecula, CA 92593

(909) 676-2768

Fax: 695-1778

Picayune Rancheria of Chukchansi Indians

Dixie Jackson (Chairwoman) 46575 Road 417

Coarsegold, CA 93614

(559) 683-6633

Fax: 683-0599 


\section{Federally recognized California tribes}

Pala Band of Mission Indians

Robert Smith (Chairman)

Luiseño - Cupeño

Post Office Box 50

Pala, CA 92059

(760) 742-3784

Fax: 742-1411

Pauma/Yuima Band of Mission Indians

Chris Devers (Chairman)

Luiseño

Post Office Box 369

Pauma Valley, CA 92061

(760) 742-1289

Fax: 742-3422

Potter Valley Rancheria

Salvador Rosales (Chairman)

112 North School Street

Ukiah, CA 95482

(707) 462-1213

Fax: 462-1240

Quartz Valley Reservation

Roy Lincoln (Chairman)

Post Office Box 24

Fort Jones, CA 96032

(530) 468-5907

Fax: 468-5908
Pinoleville of Pomo Indians

Leona Williams (Chairwoman)

367 N. State Street Suite 204

Ukiah, CA 95482

(707) 463-1454

Fax: 463-6601

Pit River Tribal Council

Gene Preston (Chairman)

37014 Main Street

Burney, CA 96013

(530) 335-5421

Fax: 335-3140

Risighini Rancheria

Rick Dowd (Chairman)

P.O. Box 529

Klamath, CA 95548

P:707-482-2431

F:707-482-3425
Rincon San Luiseño Band of Mission Indians

John Currier (Chairman)

Post Office Box 68

Valley Center, CA 92082

(760) 749-1051

Fax: 749-8901 


\section{Federally recognized California tribes}

Ramona (Cahuilla) Band of Mission

Indians

Manuel Hamilton

P.O. Box 391372

Anza, CA 92539

(909) 763-4105

Fax: 763-4325

Redding Rancheria

Tracy Edwards (Chairman)

Wintun, Pit River \& Yana

2000 Redding Rancheria Road

Redding, CA 96001

(530) 225-8979

Fax: 241-1879

Redwood Valley Rancheria

Elizabeth Hansen (Chairwoman)

Little River Band of Pomo Indians

3250 Road I

Redwood Valley, CA 95470- 9526

(707) 485-0361

Fax: 485-5726

Rumsey Rancheria

Paula Lorenzo (Chairwoman)

Wintun

Post Office Box 18

Brooks, CA 95606

(530) 796-3400

Fax: 796-2143
Robinson Rancheria of Pomo Indians

Clara Wilson (Chairwoman)

1545 E Highway 20

Nice, CA 95464

(707) 275-0527

Fax: 275-2151

Bear River Band of Rohnerville Rancheria James Moon Jr. (Chairman) 32 Bear River Drive Loleta, CA 95551

(707) 733-1900

Fax: (707) 733-1972

Round Valley Reservation

Debra Oliver (Chairwoman)

Achomawi, Concow, Nomelaki, Wailaki, Wintun, Yuki \& Pomo

Post Office Box 448

Covelo, CA 95428

(707) 983-6126

Fax: 983-612

Santa Ynez Band of Chumash Indians

Vincent Armenta (Chairman)

P. O. Box 517

Santa Ynez, CA 93460

(805) 688-7997

Fax: 686-9578 


\section{Federally recognized California tribes}

San Manuel Band of Mission Indians

Darren Marquez (Chairman)

Serrano

P.O. Box 266

Patton, CA 92369

(909) 864-8933

Fax: 864-3370

San Pasqual Band of Diegueño Indians

Allen E. Lawson (Chairman)

Post Office Box 365

Valley Center, CA 92082

(760) 749-3200

Fax: 749-3876

Santa Rosa Rancheria

Michael Sisco (Chairman)

P.O. Box 8

Lemoore, CA 93245

(559) 924-1278

Fax: 924-3583

Santa Rosa Reservation

Christina Arzate (Chairmwoman)

P.O. Box 365

Valley Center, CA 92082

(909) 763-5140

Fax: 763-9781
Santa Ysabel Band of Mission Indians Johnny Hernendez (Chairman)

Kumeyaay (Diegueño)

Post Office Box 130

Santa Ysabel, CA 92070

(760) 765-0845

Fax: 765-0320

Scotts Valley (Rancheria) Band of Pomo Indians of the Sugar Bowl

Don Arnold (Chairman)

Soda Bay Road

Kelseyville, CA 954951

(707) 277-8870

Fax: 277-8874

Sherwood Valley Rancheria of Pomo Indians

Alen J. Wright (Chairman)

190 Sherwood Hill Drive

Willits, CA 95490

(707) 459-9690

Fax: 459-6936

Shingle Springs Rancheria

Nicholas Fonseca (Chairman)

Maidu

Post Office Box 1340

Shingle Springs, CA 95682

(530) 676-8010

Fax: 676-8033 


\section{Federally recognized California tribes}

Smith River Rancheria

Kara Miller (Chairwoman)

250 North Indian Road

Smith River, CA 95567-9525

(707) 487-9255

Fax. 487-0930

Soboba Band of Mission Indians

Robert Salgado Sr. (Chairman)

Luiseño

Post Office Box 487

San Jacinto, CA 92583

(909) 654-2765

Fax: 654-4198

Stewart's Point Rancheria

Lester Pinola (Chairman)

Kashaya Pomo

3535 Industrial Dr., Suite B-2

Santa Rosa, CA 95403

(707) 591-0580

Fax: 591-0583

Susanville Rancheria

Valerie Edwards (Chairwoman)

Paiute, Maidu, Pit River \& Washoe 745 Joaquin St.

Susanville, CA 96130

(530) 257-6264

Fax: 257-7986
Table Bluff Rancheria

Cheryl A. Seidener (Chairwoman)

Wiyot

1000 Wiyot Drive

Loleta, CA 95551

(707) 733-5055

Fax: 733-5601

Table Mountain Rancheria

Leanne Walker-Grant (Chairwoman)

Mono

Post Office Box 410

Friant, CA 93626

(559) 822-2587

Fax: 822-2693

Timba-Sha Western Shoshone

Georgia Kennedy (Chairwoman)

P.O. Box 459

Death Valley, CA 92328

(760) 786-2374

Fax: 786-2376

Torres-Martinez Band of Desert Cahuilla Indians

Raymond Torres (Chairman)

66-725 Martinez Road

P. O. Box 1160

Thermal, CA 92274

(760) 397-8144

Fax: 397-8146 


\section{Federally recognized California tribes}

\author{
Sycuan Band of Mission Indians \\ Daniel Tucker (Chairman) \\ Kumeyaay (Diegueño) \\ 5459 Sycon Road \\ El Cajon, CA 92019 \\ (619) 445-2613
}

Fax: 445-3016

Tule River

Neil Peyron (Chairman)

Yokuts

Post Office Box 589

Porterville, CA 93258

(559) 781-4271

Fax: 781-4610

Tuolumne Rancheria

Kevin Day (Chairman)

Miwok, Me Wuk, \& Yokuts

Post Office Box 699

Tuolumne, CA 94379

(209) 928-3475

Fax: 928-1677

Twenty-Nine Palms Band of Mission

Indians

Dean Mike (Chairman)

Chemehuevi

46-200 Harrison Place

Coachella, CA 92236

(760) 775-5566

Fax: 775-4638

\author{
Trinidad Rancheria \\ Carol Ervins (Chairwoman) \\ Yurok, Wiyot \& Tolowa \\ Post Office Box 630 \\ Trinidad, CA 95570 \\ (707) 677-0211 \\ Fax: 677-3921
}

\author{
Viejas Band of Mission Indians \\ Anthony R Pico \\ Post Office Box 908 \\ Alpine, CA 91903 \\ (619) $445-3810$ \\ Fax: 445-5337
}

Yurok Tribe

Susan Masten (Chairwoman)

P.O. Box 1027

Kalmath, CA 95548

(707) 482-1350

Fax: 482-1377

Ione Band of Miwok

Kathryn Ramey (Interm-Chairwoman)

P. O. Box 1190

Ione, CA 95640

(209) 274-6753

Fax: 274-6636 


\section{Federally recognized California tribes}

United Auburn Indian Community

Jessica Taveres (President)

661 Newcastle Road, Suite 1

Newcastle, CA 95658

(916) 663-3720

Fax: 663-3727

Upper Lake Rancheria

Carmella Icay-Johnshon (Chairwoman)

P.O. Box 516

Upper Lake, CA 95485

(707) 275-0737

Fax: 275-0757

California Valley Miwok Tribe

Silvia Burley (Chairwoman)

10601 Escondido PI.

Stockton, CA 95212

(209) 931-4567

Fax: 931-4333

Washoe Tribe of Nevada and California ${ }^{1}$

A. Brian Wallace, (Chairman)

919 Hwy 395 South

Garnerville, Nevada 89410

(775) 265-41912

Fax: (775) 265-6240
Augustine Band of Mission Indians Maryann Martin, (Chairwoman) 1185 Hargrave Street

Banning, CA 92220-2633

(909) 922-9727

No Fax

(Central California)

Enterprise Rancheria

Harvey Angle (Chairman)

1940 Feather River Blvd., Suite B

Oroville, CA 95965

(530) 532-9214

Fax: 532-1768

Colorado River Indian Tribes

Daniel Eddy Jr, (Chairman)

Route 1, Box 23-B

Parker, Arizona 85344

(928) 669-9211

Fax: (928) 669-1391

Quechan Tribe-Fort Yuma ${ }^{1}$

Mike Jacson, Sr, (President)

P.O. Box 1899

Yuma, AZ 85366

(760) 572-0213

Fax: (928) 572-2102 


\section{Federally recognized California tribes}

\author{
Fort Mojave ${ }^{1}$ \\ Nora McDowell, (Chairwoman) \\ 500 Merriman Avenue \\ Needles, CA 92363 \\ (760) 629-4591 \\ Fax: (760) 629-5767
}

\author{
Chemehuevi Indian Tribe ${ }^{1}$ \\ Edward D. Smith, (Chairman) \\ P.O. Box 1976 \\ Havasu Lake, CA 92363 \\ (760) 858-4301 \\ Fax: (760) 858-5400
}

\footnotetext{
${ }^{1}$ Tribe with land in two states
} 
Federally Recognized California Tribes

\begin{tabular}{|c|c|c|c|c|c|c|c|}
\hline Tribe & Priority Tribal Water Issues & Agriculture & Land & Pop & Economic Development & $\begin{array}{c}\text { Environmental } \\
\text { Department }\end{array}$ & Contacts \\
\hline $\begin{array}{l}\text { Hoopa Valley } \\
\text { Tribe }\end{array}$ & $\begin{array}{l}\text { A.) Determining the type of wastewater } \\
\text { treatment plant to build (improve septic } \\
\text { tanks or build a wastewater treatment } \\
\text { plant) } \\
\text { Ba) } \\
\text { B.) In the process of placing a water } \\
\text { system in the Trinity River, because } \\
\text { water from the creeks are drying up } \\
\text { (water supply) }^{(\text {a) }} \\
\text { C.) Contamination from spills \& solid } \\
\text { wastes into river embankments }\end{array}$ & $\begin{array}{l}\text { No large scale } \\
\text { farming; } \\
\text { Small family } \\
\text { gardens }^{(a)}\end{array}$ & $142 \mathrm{mi}^{2(c)}$ & $2,633^{(c)}$ & $\begin{array}{l}\text { Lucky Bear Casino; Timber } \\
\text { sales; cellular tower (cell } \\
\text { phones); saw mill } \\
\text { development; modular } \\
\text { housing plant; future tourist } \\
\text { campground; future outdoor } \\
\text { amphitheatre for concerts } \\
\text { and summer fests } \\
\text { an) }\end{array}$ & \begin{tabular}{|l|} 
Hoopa Public Utility \\
Dept \\
Nolan Colegrove \\
Natural Resource \\
Director \\
Phone: (530) 625-4284 \\
Email: \\
nolan@ @cweb.net
\end{tabular} & $\begin{array}{l}\text { Clifford L. Marshall } \\
\text { Chairman } \\
\text { Post Office Box } 1348 \\
\text { Hoopa, CA 95546 } \\
\text { Phone: (530) 625-4211 } \\
\text { Fax: (530) 625-4594 }\end{array}$ \\
\hline Yurok Tribe & $\begin{array}{l}\text { A.) Concerned with the impacts from } \\
\text { upstream mining, timber harvest, dams, } \\
\text { agriculture and development } \\
\text { B.) Issues with drinking water and waste } \\
\text { water } \\
\text { C.) No waste water treatment plants; } \\
\text { currently using septic tanks }{ }^{(a)}\end{array}$ & $\begin{array}{l}\text { No large scale } \\
\text { farming; Small } \\
\text { family gardens }^{(a)}\end{array}$ & $85 \mathrm{mi}^{2(c)}$ & $4,584^{(a)}$ & \begin{tabular}{|l|} 
Commercial fishery; future \\
Interstate Travel Center \\
Service; future Eco Lodge; \\
contracts to harvest a portion \\
of forested land \\
\end{tabular} & \begin{tabular}{|l|} 
Yurok Environmental \\
Office \\
Kevin McKernan \\
Environmental \\
Director \\
Phone: (707) 488-0108 \\
Email: \\
kevin@yurok.com \\
\end{tabular} & $\begin{array}{l}\text { Susan Masten } \\
\text { Chairwoman } \\
\text { Post Office Box } 1027 \\
\text { Klamath, CA 95548 } \\
\text { Phone: (707) 482-1350 } \\
\text { Fax: (707) 482-1377 }\end{array}$ \\
\hline $\begin{array}{l}\text { Round Valley } \\
\text { Reservation }\end{array}$ & $\begin{array}{l}\text { A.) Contact the Tribal Chairwoman to } \\
\text { request water issues }^{(a)} \\
\text { B.) Stream restoration } \\
\text { (d) }\end{array}$ & No info & $36 \mathrm{mi}^{2(\mathrm{c})}$ & $2,615^{(b)}$ & \begin{tabular}{|l|} 
Potential economy lies in the \\
rich soil, water, timber sales. \\
Employment opportunities in \\
the timber, tourism and \\
recreation industries, \\
agricultural projects and \\
tribal government
\end{tabular} & \begin{tabular}{|l|} 
Natural Resources \\
Department \\
Charles Thompson \\
Natural Resources \\
Director
\end{tabular} & \begin{tabular}{|l|} 
Debra Oliver \\
Chairwoman \\
Post Office Box 448 \\
Covelo, CA 95428 \\
Phone: (707) $983-6126$ \\
Fax: (707) $983-6128$ \\
\end{tabular} \\
\hline
\end{tabular}




\section{Federally Recognized California Tribes}

\begin{tabular}{|c|c|c|c|c|c|c|c|}
\hline $\begin{array}{l}\text { Bishop } \\
\text { Reservation }\end{array}$ & $\begin{array}{l}\text { A.) Water quality monitoring for benthic } \\
\text { macroinvertebrates, E. Coli, Total } \\
\text { Coliform } \\
\text { B.) Have a couple of years of collecting } \\
\text { base line water quality data, now what? } \\
\text { C.) Water lab is being used by other } \\
\text { tribes in the Owens Valley }\end{array}$ & $\begin{array}{l}\text { No large scale } \\
\text { farming }^{(\text {a) }}\end{array}$ & $1.4 \mathrm{mi}^{2(\mathrm{c})}$ & $\begin{array}{c}1,351^{(\mathrm{a}} \\
)\end{array}$ & $\begin{array}{l}\text { Paiute Palace casino; other } \\
\text { economic development } \\
\text { projects in the planning } \\
\text { stages }^{(a)}\end{array}$ & $\begin{array}{l}\text { Environmental } \\
\text { Management Office }\end{array}$ & $\begin{array}{l}\text { Dough Vega, } \\
\text { Chairman } \\
\text { Post Office Box } 548 \\
\text { Bishop, CA } 93515 \\
\text { Phone: }(760) 873-3584 \\
\text { Fax: }(760) 873-4143\end{array}$ \\
\hline $\begin{array}{l}\text { Karuk Tribe of } \\
\text { California }\end{array}$ & $\begin{array}{l}\text { A.) No drinking water system } \\
\text { B.) High water contamination (E Coli and } \\
\text { Total Coliform) } \\
\text { C.) Recently submitted a draft of their } \\
\text { water control plan }^{(a)}\end{array}$ & $\begin{array}{l}\text { No large scale } \\
\text { farming }^{(a)}\end{array}$ & $\begin{array}{l}1 \mathrm{mi}^{2(\mathrm{c})} \\
\text { very small } \\
\text { parcels } \\
\text { along river }\end{array}$ & $\begin{array}{c}3,222^{(a} \\
{ }^{a}\end{array}$ & $\begin{array}{l}\text { Timber sales; employment } \\
\text { within the U.S. Forest } \\
\text { Service }^{(\text {a) }}\end{array}$ & $\begin{array}{l}\text { Department of } \\
\text { Natural Resources } \\
\text { P.O. Box } 282 \\
\text { Orleans, CA } 9556\end{array}$ & $\begin{array}{l}\text { Alvis Johnson } \\
\text { Chairman } \\
\text { Post Office Box } 1016 \\
\text { Happy Camp, CA } \\
96039 \\
\text { Phone: }(530) 493-5305 \\
\text { Fax: }(530) 493-5322 \\
\end{array}$ \\
\hline $\begin{array}{l}\text { La Jolla Band } \\
\text { of Luiseno } \\
\text { Indians }\end{array}$ & 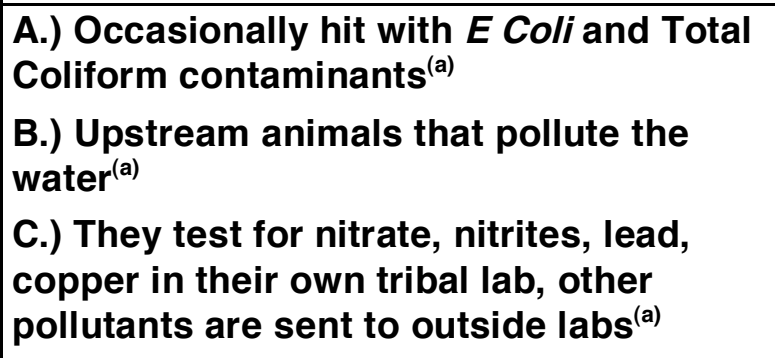 & $\begin{array}{l}\text { No large scale } \\
\text { farming; Small } \\
\text { family gardens }\end{array}$ & $14 \mathrm{mi}^{2(\mathrm{c})}$ & $390^{(c)}$ & $\begin{array}{l}\text { Sengme Oaks Water Park } \\
\text { since 1984; campground }^{(a)}\end{array}$ & $\begin{array}{l}\text { Water and Natural } \\
\text { Resources Dept }\end{array}$ & $\begin{array}{l}\text { Wendy Schlater } \\
\text { Chairwoman } \\
2200 \text { Highway } 76 \\
\text { Pauma Valley, CA } \\
92061 \\
\text { Phone: (760) } 742-3771 \\
\text { Fax: (707) 482-1377 }\end{array}$ \\
\hline $\begin{array}{l}\text { Colorado } \\
\text { River Indian } \\
\text { Tribes }\end{array}$ & $\begin{array}{l}\text { A.) Finding adequate clean drinking } \\
\text { water } \\
\text { B.) As a result of the drought on the } \\
\text { Colorado River system, a concern is the } \\
\text { preparedness for future water } \\
\text { shortages }^{(a)} \\
\text { C.) Efficient use of irrigation water }\end{array}$ & $\begin{array}{l}\text { Approx. } 84,500 \text { ac of } \\
\text { fertile land for } \\
\text { cotton, alfalfa, } \\
\text { wheat, feed grains, } \\
\text { lettuce and } \\
\text { melons. }\end{array}$ & $\begin{array}{c}269,921 \\
\mathrm{ac}^{(\mathrm{b})} \\
(42,696 \text { ac in } \\
\mathrm{CA})\end{array}$ & $\begin{array}{c}3,098^{(b} \\
1\end{array}$ & $\begin{array}{l}\text { Blue Water Resort and } \\
\text { Casino; Blue Water Marine } \\
\text { Park; Avi Suquilla Airport; } \\
\text { agriculture; plastics } \\
\text { manufacturer }^{(\text {b) }}\end{array}$ & \begin{tabular}{|l|} 
Environmental \\
Protection Office \\
Gary Handson \\
Water Resource \\
Director \\
Phone: (928) 669-1381 \\
Email: \\
crith20@ rraz.net \\
\end{tabular} & $\begin{array}{l}\text { Daniel Eddy, Jr. } \\
\text { Chairman } \\
\text { P.O. Box 23-B } \\
\text { Parker, AZ 85344 } \\
\text { Phone: (928) 669-9211 } \\
\text { Fax: (925) 669-1391 }\end{array}$ \\
\hline
\end{tabular}




\section{Federally Recognized California Tribes}

\begin{tabular}{|c|c|c|c|c|c|c|c|}
\hline Tribe & Priority Tribal Water Issues & Agriculture & Land & Pop & Economic Development & $\begin{array}{c}\text { Environmental } \\
\text { Department }\end{array}$ & Contacts \\
\hline $\begin{array}{l}\text { Pechanga } \\
\text { Band of } \\
\text { Mission } \\
\text { Indians }\end{array}$ & $\begin{array}{l}\text { A.) Concern regarding groundwater } \\
\text { contamination from neighboring farmers' } \\
\text { pesticides }^{(a)} \\
\text { B.) Surface water bacteria a mild } \\
\text { problem }^{\text {(a) }}\end{array}$ & $\begin{array}{l}\text { No large scale } \\
\text { farming; Small } \\
\text { family gardens }\end{array}$ & $7 \mathrm{mi}^{2(\mathrm{c})}$ & $420^{(c)}$ & Pechanga Gaming Center ${ }^{(\mathrm{e})}$ & $\begin{array}{l}\text { Pechanga Water } \\
\text { Systems }\end{array}$ & $\begin{array}{l}\text { Mark Maccrro } \\
\text { Chairman } \\
\text { P.O. Box } 1477 \\
\text { Temecula, CA } 92593 \\
\text { Phone: (909) } 676-2768 \\
\text { Fax: (909) } 676-1778\end{array}$ \\
\hline Tule River & $\begin{array}{l}\text { A.) Dan Schultz will try to call back with } \\
\text { information }^{(a)}\end{array}$ & $\begin{array}{l}\text { No large scale } \\
\text { farming; Small } \\
\text { family gardens }\end{array}$ & $85 \mathrm{mi}^{2(c)}$ & $850^{(\text {b) }}$ & $\begin{array}{l}\text { Eagle Mountain Casino }{ }^{(\mathrm{e})} ; \\
\text { Abundant timber resources } \\
\text { for revenue \& employment }\end{array}$ & \begin{tabular}{|l|} 
Dan Schultz \\
Water Resource \\
Director \\
Phone: (559) 781- \\
4271, x114 \\
Email: \\
tule_naturalresources \\
@yahoo.com \\
\end{tabular} & \begin{tabular}{|l|} 
Neil Peyron \\
Chairman \\
P.O. Box 589 \\
Porterville, CA 93258 \\
Phone: (559) 781-4271 \\
Fax: (559) 781-4610 \\
\end{tabular} \\
\hline $\begin{array}{l}\text { Jackson } \\
\text { Rancheria } \\
\text { Band of } \\
\text { Mewuk } \\
\text { Indians }\end{array}$ & $\begin{array}{l}\text { A.) Mike Fuentes recommended letter } \\
\text { addressed to the Chairwoman requesting } \\
\text { top water issues }{ }^{(a)}\end{array}$ & No info & $0.49 \mathrm{mi}^{2(\mathrm{c})}$ & $30^{(a)}$ & Jackson Casino ${ }^{(\mathrm{e})}$ & \begin{tabular}{|l|} 
Water Distribution \\
Systems \\
Mike Fuentes, \\
Manager \\
Water Treatment \\
Systems
\end{tabular} & \begin{tabular}{|l} 
Margret Dalton \\
Chairwoman \\
P.O. Box 1090 \\
Jackson, CA 95642 \\
Phone: (209) 223-1935 \\
Fax: (209) 223-5366
\end{tabular} \\
\hline $\begin{array}{l}\text { Agua Caliente } \\
\text { Band of } \\
\text { Chauilla } \\
\text { Indians }\end{array}$ & $\begin{array}{l}\text { A.) The tribe is focusing on testing their } \\
\text { groundwater, funded by EPA grants } \\
\text { B.) Establishing a water code } \\
\text { (a) } \\
\text { C.) Searching for a method to maintain } \\
\text { water records and measurements of } \\
\text { groundwater and surface water }^{(a)}\end{array}$ & $\begin{array}{l}\text { No large scale } \\
\text { farming }^{(a)}\end{array}$ & $49 \mathrm{mi}^{2(\mathrm{c})}$ & $385^{(a)}$ & $\begin{array}{l}\text { Spa Hotel \& Casino(e); } \\
\text { Canyon Park for hiking and } \\
\text { trails; trading post }{ }^{(\mathbf{b})}\end{array}$ & \begin{tabular}{|l|} 
Natural Resources \\
Department \\
Tom Davis, Chief \\
Planning Officer \\
Phone: (760) 325-3400 \\
Email: \\
tdavis@aguacaliente. \\
net
\end{tabular} & $\begin{array}{l}\text { Richard M. Milanovich } \\
\text { Chairman } \\
600 \text { East Tahquitz } \\
\text { Canyon Way } \\
\text { Palm Springs, CA } \\
92262 \\
\text { Phone: (760) 325-3400 } \\
\text { Fax: (760) 235-4954 } \\
\end{array}$ \\
\hline
\end{tabular}




\section{Federally Recognized California Tribes}

Tribe Priority Tribal Water Issues

Agriculture

Land

Pop

Economic Development

\begin{tabular}{|c|c|c|c|c|c|c|c|}
\hline Pit River Tribe & $\begin{array}{l}\text { A.) Facing a problem of geothermal wells } \\
\text { with a high concentration of iron and } \\
\text { magnesium for drinking water }{ }^{(a)} \\
\text { B.) Need process for developing water } \\
\text { quality standards } \\
\text { C.) Drinking water contamination (issues } \\
\text { with } E \text { Coli, temperature, dissolved } \\
\text { oxygen, nutrients, and bacteria) }^{(a)}\end{array}$ & $\begin{array}{l}\text { No large scale } \\
\text { farming }\end{array}$ & \begin{tabular}{|c|}
$411 \mathrm{mi}^{2(c)}$ \\
$11,526 \mathrm{ac}^{(\mathrm{a})}$
\end{tabular} & $\begin{array}{c}2,300^{(a)} \\
)\end{array}$ & $\begin{array}{l}\text { Pit River Casino; sub-lease } \\
\text { land to ranchers }\end{array}$ & \begin{tabular}{|l|} 
Pit River \\
Environmental Office \\
Chris Pirosko \\
Water Resources \\
Coordinator/Hydrolog \\
ist \\
Phone: $(530) 335-5062$
\end{tabular} & $\begin{array}{l}\text { Gene Preston, } \\
\text { Chairman } \\
\text { 37014 Main Street } \\
\text { Burney, CA 96013 } \\
\text { Phone: (530) 335-5421 } \\
\text { Fax: (530) 335-3140 }\end{array}$ \\
\hline $\begin{array}{l}\text { Bear River } \\
\text { Band of the } \\
\text { Rohnerville } \\
\text { Rancheria }\end{array}$ & $\begin{array}{l}\text { A.) Developing their water quality } \\
\text { standards }^{(a)} \\
\text { B.) Researching a wastewater treatment } \\
\text { plant }^{(a)} \\
\text { C.) Wrote a proposal for groundwater } \\
\text { grant, high sodium in drinking water } \\
\text { D.) Wrote a proposal for surface water } \\
\text { grant to begin monitoring their water }\end{array}$ & $\begin{array}{l}\text { No large scale } \\
\text { farming }^{(a)}\end{array}$ & $62 \mathrm{ac}^{(\mathrm{a})}$ & $98^{(\mathrm{c})}$ & $\begin{array}{l}\text { Federal government grants } \\
\text { (EPA, IHA BIA, etc); } \\
\text { proposing to build a casino } \\
\text { and restaurant }\end{array}$ & $\begin{array}{l}\text { Tribal Environmental } \\
\text { Dept } \\
\text { Ed Smith } \\
\text { Environmental } \\
\text { Coordinator }\end{array}$ & $\begin{array}{l}\text { James Moon, Jr. } \\
\text { Chairman } \\
32 \text { Bear River Drive } \\
\text { Loleta, CA 9551 } \\
\text { Phone: (707) 733-1900 } \\
\text { Fax: (707) 733-1972 }\end{array}$ \\
\hline $\begin{array}{l}\text { Benton Paiute } \\
\text { Reservation }\end{array}$ & $\begin{array}{l}\text { A.) A tribal spokesperson would not } \\
\text { release any information, except that they } \\
\text { do not have a water department }{ }^{(a)}\end{array}$ & No farming ${ }^{(b)}$ & $0.23 \mathrm{mi}^{2(\mathrm{c})}$ & $75^{(\mathrm{b})}$ & $\begin{array}{l}\text { Service station; commercial } \\
\text { trailer park }^{(\mathbf{b})}\end{array}$ & No water department & \begin{tabular}{|l} 
Joseph Salt, \\
Chairman \\
567 Yellow Jacket \\
Benton, CA 93512 \\
Phone: (760) $933-2321$ \\
Faz: $(760) 933-2412$
\end{tabular} \\
\hline
\end{tabular}




\section{Federally Recognized California Tribes}

\begin{tabular}{|c|c|c|c|c|c|c|c|}
\hline $\begin{array}{l}\text { Los Coyotes } \\
\text { Band of } \\
\text { Mission } \\
\text { Indians }\end{array}$ & $\begin{array}{l}\text { A.) In the process of analyzing their water } \\
\text { system for approval of a public drinking } \\
\text { water system }^{(a)} \\
\text { B.) Seeking grants to replace system that } \\
\text { is currently leaking } \\
\text { C.) Researching how to protect their } \\
\text { water source }^{(a)}\end{array}$ & $\begin{array}{l}\text { No large scale } \\
\text { farming; tribal land } \\
\text { has } 17 \% \text { slopes }^{(a)}\end{array}$ & $\begin{array}{c}25,050 \mathrm{ac}^{(\mathrm{b})} \\
39 \mathrm{mi}^{2(\mathrm{c})}\end{array}$ & $\begin{array}{c}212^{(\mathrm{b})} \\
70^{(\mathrm{c})}\end{array}$ & $\begin{array}{l}\text { Federal government grants; } \\
\text { campground }^{(a)}\end{array}$ & $\begin{array}{l}\text { Environmental Office } \\
\text { Melody Sees } \\
\text { EPA Director }\end{array}$ & $\begin{array}{l}\text { Catheryn Saubel } \\
\text { Chairwoman } \\
\text { P.O. Box } 189 \\
\text { Warner Springs, CA } \\
92086 \\
\text { Phone: (707) } 575-5917 \\
\text { Fax: (707) } 575-6974\end{array}$ \\
\hline $\begin{array}{l}\text { Santa Ysabel } \\
\text { Band of } \\
\text { Mission } \\
\text { Indians }\end{array}$ & $\begin{array}{l}\text { A.) Max Baay is on travel, returns } 8 / 4 / 03 \text {. } \\
\text { He's recovering from an accident }{ }^{(a)}\end{array}$ & No info & $\begin{array}{l}24 \mathrm{mi}^{2(\mathrm{c})} \\
1,500 \mathrm{ac}^{(\mathrm{a})}\end{array}$ & $750^{(a)}$ & $\begin{array}{l}\text { Federal government grants; } \\
\text { negotiating with state for a } \\
\text { casino compact }^{\text {(a) }}\end{array}$ & $\begin{array}{l}\text { Max Baay } \\
\text { Water Personnel }\end{array}$ & $\begin{array}{l}\text { Johnny Hernendez } \\
\text { Chairman } \\
\text { P.O. Box } 130 \\
\text { Santa Ysabel, CA } \\
92070 \\
\text { Phone: }(760) 765-0845 \\
\text { Fax: }(760) 765-0320\end{array}$ \\
\hline $\begin{array}{l}\text { Coyote Valley } \\
\text { Band of Pomo } \\
\text { Indians }\end{array}$ & $\begin{array}{l}\text { A.) Better understanding of how to run } \\
\text { small drinking water treatment plant and } \\
\text { capacity to train staff to operate the }_{\text {plant }^{(a)}} \\
\text { B.) Seeking to improve and enlarge their } \\
\text { water storage tank }^{(a)} \\
\text { C.) Researching wastewater treatment } \\
\text { plants, as opposed to septic tanks }^{(a)}\end{array}$ & $\begin{array}{l}\text { No large scale } \\
\text { farming; only } \\
\text { walnut groves, but } \\
\text { not harvesting } \\
\text { them } \\
\text { (a) }\end{array}$ & $85 a^{(a)}$ & $\begin{array}{l}225^{(\mathbf{b})} \\
104^{(\text {c) }}\end{array}$ & $\begin{array}{l}\text { Shodakai Casino(a); cabinet } \\
\text { shop }^{(b)}\end{array}$ & \begin{tabular}{|l} 
Tribal EPA \\
Jeff Harris \\
EPA Teacher
\end{tabular} & $\begin{array}{l}\text { Pricilla Hunter } \\
\text { Chairwoman } \\
\text { P.O. Box } 39 \\
\text { Redwood Valley, CA } \\
95470 \\
\text { Phone: (707) 485-8723 } \\
\text { Fax: (707) 485-1247 }\end{array}$ \\
\hline $\begin{array}{l}\text { Trinidad } \\
\text { Rancheria }\end{array}$ & $\begin{array}{l}\text { A.) Wastewater issues of their } \\
\text { decentralized treatment system, some } \\
\text { problems with septic tanks and leach } \\
\text { fields }{ }^{(a)} \\
\text { B.) Monitoring \& detecting sewage water } \\
\text { in surface water }{ }^{(a)} \\
\text { C.) They do not conduct ocean }\end{array}$ & $\begin{array}{l}\text { No large scale } \\
\text { farming }\end{array}$ & $47^{(\mathrm{b})}$ & $106^{(a)}$ & $\begin{array}{l}\text { Cher-Ae Heights Casino; } \\
\text { motel; restaurants; harbor }{ }^{(a)}\end{array}$ & \begin{tabular}{|l} 
Greg Nesty \\
Trinidad Environ \\
Coordinator
\end{tabular} & $\begin{array}{l}\text { Carol Ervins, } \\
\text { Chairman } \\
\text { P.O. Box } 630 \\
\text { Trinidad, Ca } 95570 \\
\text { Phone: (707) 677-0211 } \\
\text { Fax: (707) 677-3921 }\end{array}$ \\
\hline
\end{tabular}




\section{Federally Recognized California Tribes}

Priority Tribal Water Issues

Agriculture

Land

Pop

Economic Development

monitoring for contaminants ${ }^{(a)}$

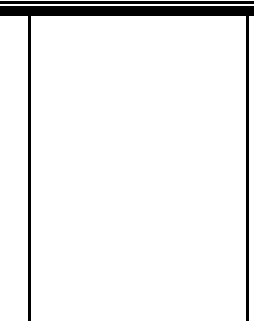

(1)

\section{Notes}
(a) Data from tribe
(b) Data from Tiller's Guide to Indian Country*
(c) Data from the U.S. Census Bureau 2000
(d) Data from Reina Rogers, USDA American Indian
Liaison
(e) Data from CA Gaming Control Commission
(*) Tiller, Veronica E. Velarder. Tiller's Guide to Indian
Country: Economic Profiles of American Reservations.
Bow Arrow Publishing Company. Albuquerque, NM. 1996. 
Appendix D: Presentation of Tribal Report

\section{California Tribal Mations Technical Water Round Table}

flugust 13, 2003

Primary Investigator: Colin Ben, Summer Research Intern

Co-Investigator: Jessie Coty, Environmental Scientist 


\section{fibout my Background}

* Bachelors of Arts, fort Lewis College, Colorado

- Graduated:5/2002, GPA: 3.1

- Major: Southwest Studies, focus in native fmerican Studies

*. Masters of Arts, University of Arizona, Begin Fall 2003

- fimerican Indian Studies Program

*. Professional Objective

- Work to improve native American Tribes' lifestyle

- Interested in tribal water issues \& environmental remediation

* Navajo Tribal Member 


\section{Introduction}

* Tribal nations Technical Water Research Roundtable proposal resulted from the LLnL Water Initiative.

* Lack of clear understanding of California (CA) tribes' key issues $\delta$ whether LIDL research aligns with their needs.

* Research objectives: identify CA tribal technical water issues \& context within which these arise (i.e., demographics, economics, cultural issues] to propose a meaningful roundtable.

* Roundtable Objectives: raise awareness, define collaborative objectives, and agree upon next steps. 


\section{Research Constraints}

*. Issues impacting research:

- Trust issues between tribes and federal agencies [e.g., LUIL=Dept. of Energy)

- Cultural issues

- Political issues \& litigation [will sharing tribal info negatively impact tribes, thus reluctance)

- Lack of info readily auailable in literature or with agencies

- Lack of tribal environmental or water staff

- Overall, little organized information available for water issues with tribes \& tribal demographics/economic base 


\section{find there's more!!}

* Other Key Hurdles:

- Identifying key federal agency contacts for tribal information not always straightforward

- Privacy rules for releasing tribal info by EPA staff

- finswering tribal staff question, "How can LInL work with our tribe?" such that tribes comfortable in releasing info

- Tribal staff refusal to release info, especially without formal letters

- Creating an equitable \& appropriate criteria for recommending tribal invitees for the round table 


\section{General Tribal Mations Info}

* Federally Recognized native fmerican Tribes have a unique government-to-government relationship with U.S.

* Tribes work directly with federal Departments including:

- Bureau of Indian Affairs (BIA)

- Bureau of Reclamation (BOR)

- Indian Health Services (IHS)

- U.S. Environmental Protection figency (EPA)

- U.S. Department of figriculture (USDf) 


\section{California Tribal Mations}

* Federally Recognized Tribes-106

* Smallest population of tribal members-3

* Largest population of tribal members-4,584

* Smallest land base trust lands- 0 square miles

* Largest land base trust lands-141.69 square miles

* Number of Gaming Tribes-53 


\section{EPA Map of Federally Recognized Tribes}

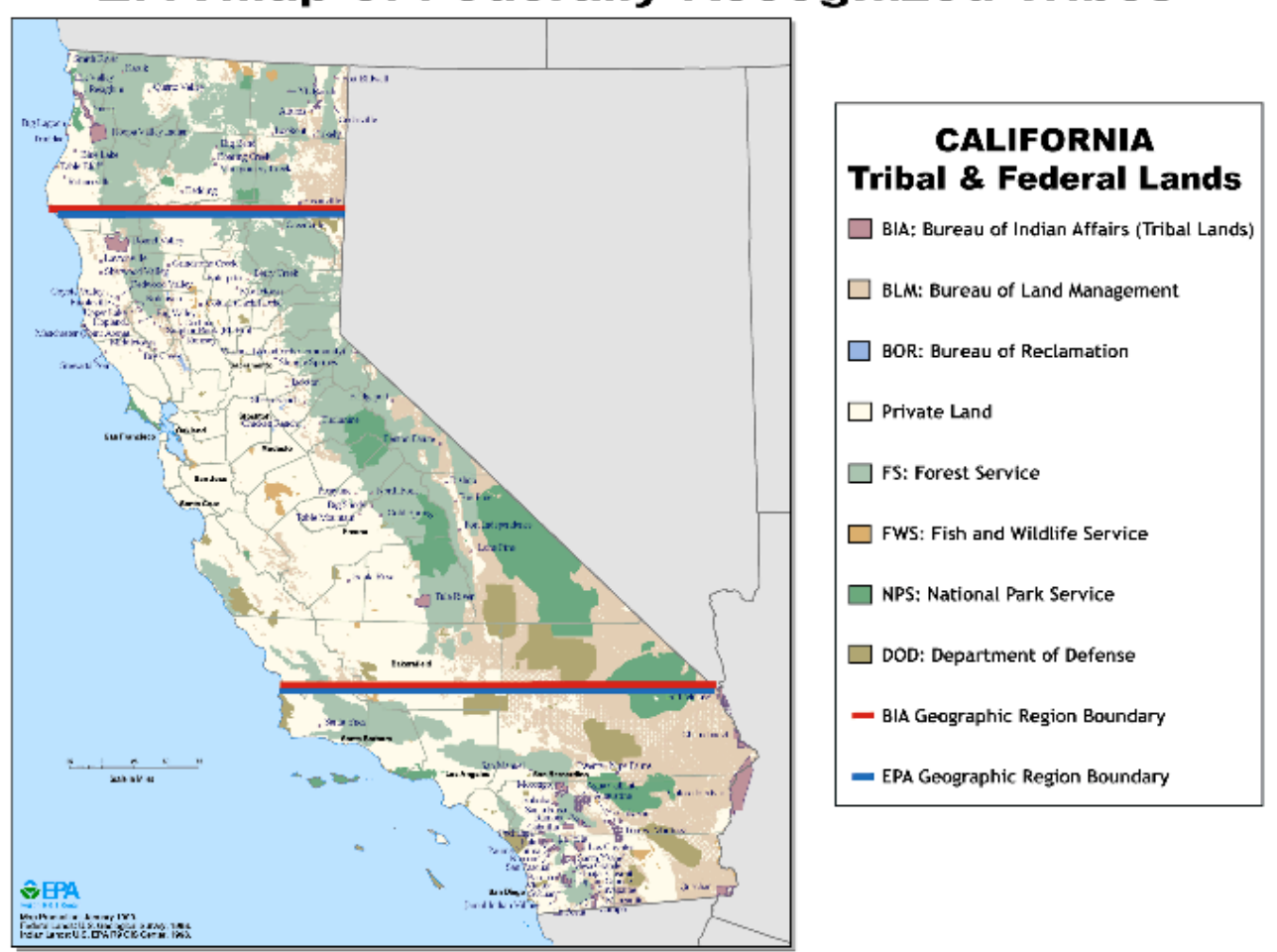




\section{Projected Water Crises by 2025}

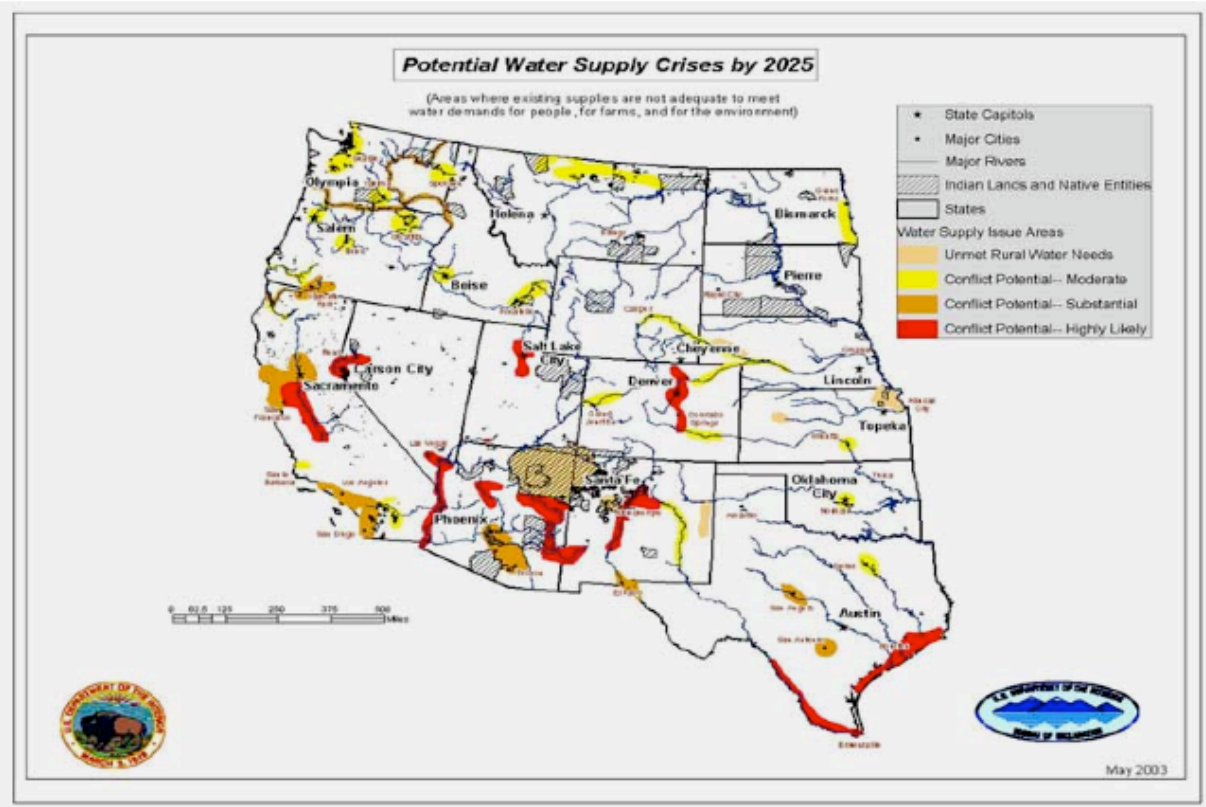




\section{Key Resources \& Contacts}

* BIf-Pacific Regional Office;

* EPf-Water Division;

\& IHS- Environmental Health Services \& Sanitation Facilities Construction;

* DOR-llative fimerican Affairs Office;

* USDA-Matural Resources Conservation Services.
*. Tribal Staff in the Environmental, Enrollment, Economic Development, \& Tribal fdministration;

* Mative fmerican Environmental Protection figency;

* Council of Energy Resources Tribes;

*. National Tribal Environmental Council. 


\section{Constraints Drove Research}

* Constraints

- Time limited capacity to research each of 106 tribes

- Focused on selecting equal number of representative regional tribes

* Geographic Regions

- Mirrored BIf \& EPA jurisdictional boundaries

- Morthern, Central, Southern areas

* Criteria: Categories of Water Programs

- Tribes with more established water programs \& departments

- Tribes with a water department and fair understanding of water issues

- Tribes with a newly established water department \& learning about water issues 


\section{(3) Applying Criteria for Tribal Selection and Research}

* Number of Tribes Per Region

- 6 for each Morthern, Central, Southern areas per region

* Number of Tribes Per Water Program Category

- 2 for each Morthern, Central, Southern areas per water category

* Selection of Tribes Per Region \& Water Program Category

- Received recommendations of tribes from federal figencies water personnel and used research information to also inform decision

- Followed up by calling each recommended tribe's water department/personnel to further justify appropriate recommendation 


\section{feedback On formula}

* Dr. Patterson, Tribal Environmental Director, La Jolla Tribe: "I think that formula would be the best way...".

* Frank fryman, State Water Rights Specialist, BIf: “It sounds pretty good."

* Ron Thompson, Director of Water Programs, national Tribal Environmental Council: “It's a good approach for a vast variety of tribes."

* Bessie Lee, Project Officer, EPA Indian Programs Office:

“Tribal participation may be greater if your discussion was a break-out session at an annual tribal conference." 


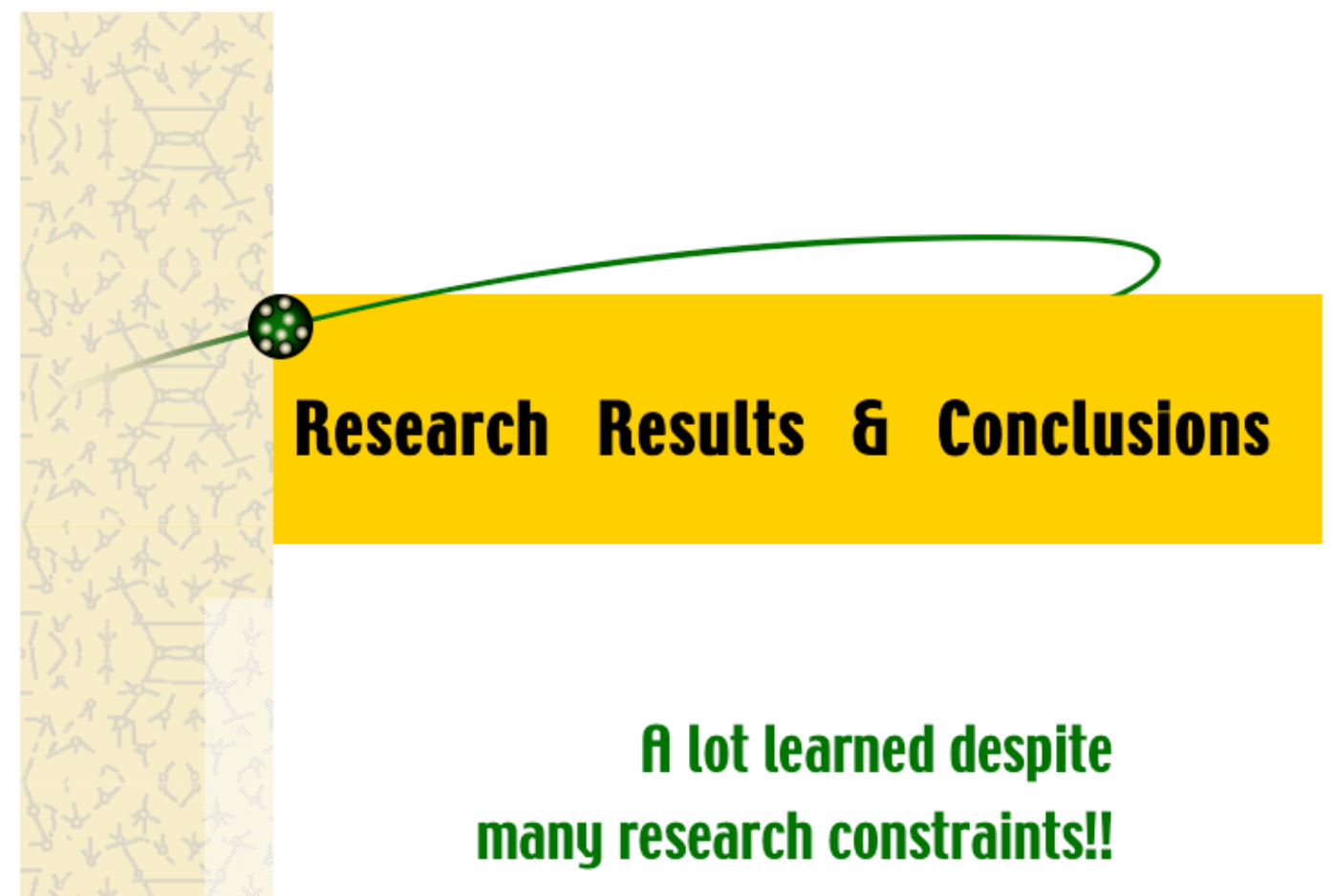




\section{California Tribal Water Issues}
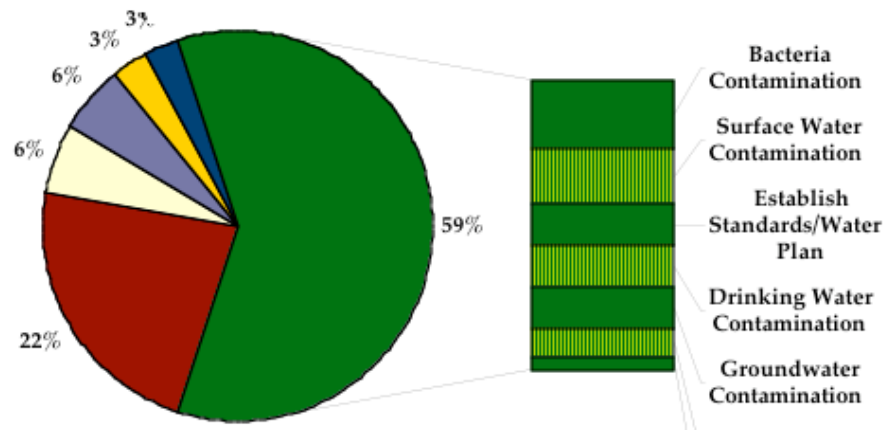

Drinking Water

Contamination

Groundwater

Contamination

- Infrastructure

Source Water

Protection

口Information Management

Ocean Monitoring

$\square$ Analytical Laboratory

$\square$ Water Scarcity/Drought

- Irrigation Efficiency

$\square$ Water Quality 


\section{Tribal Land Use \& Ownership}

Land Use
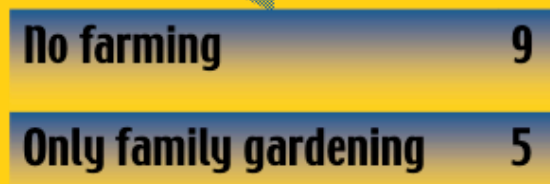

Large scale farming

no information
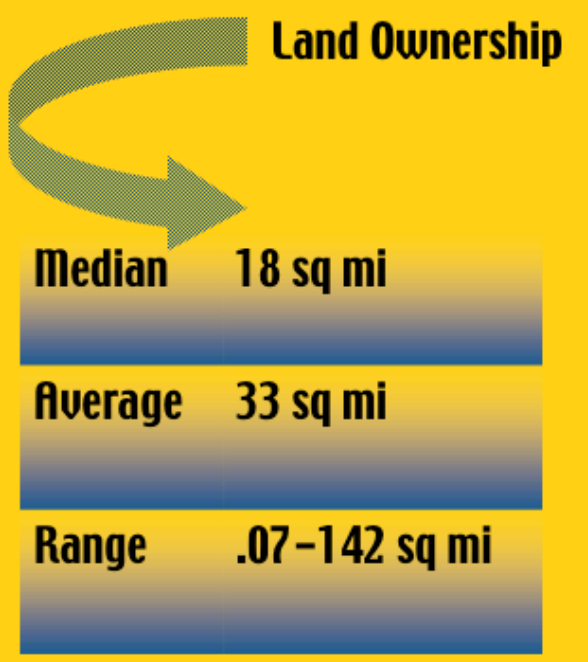


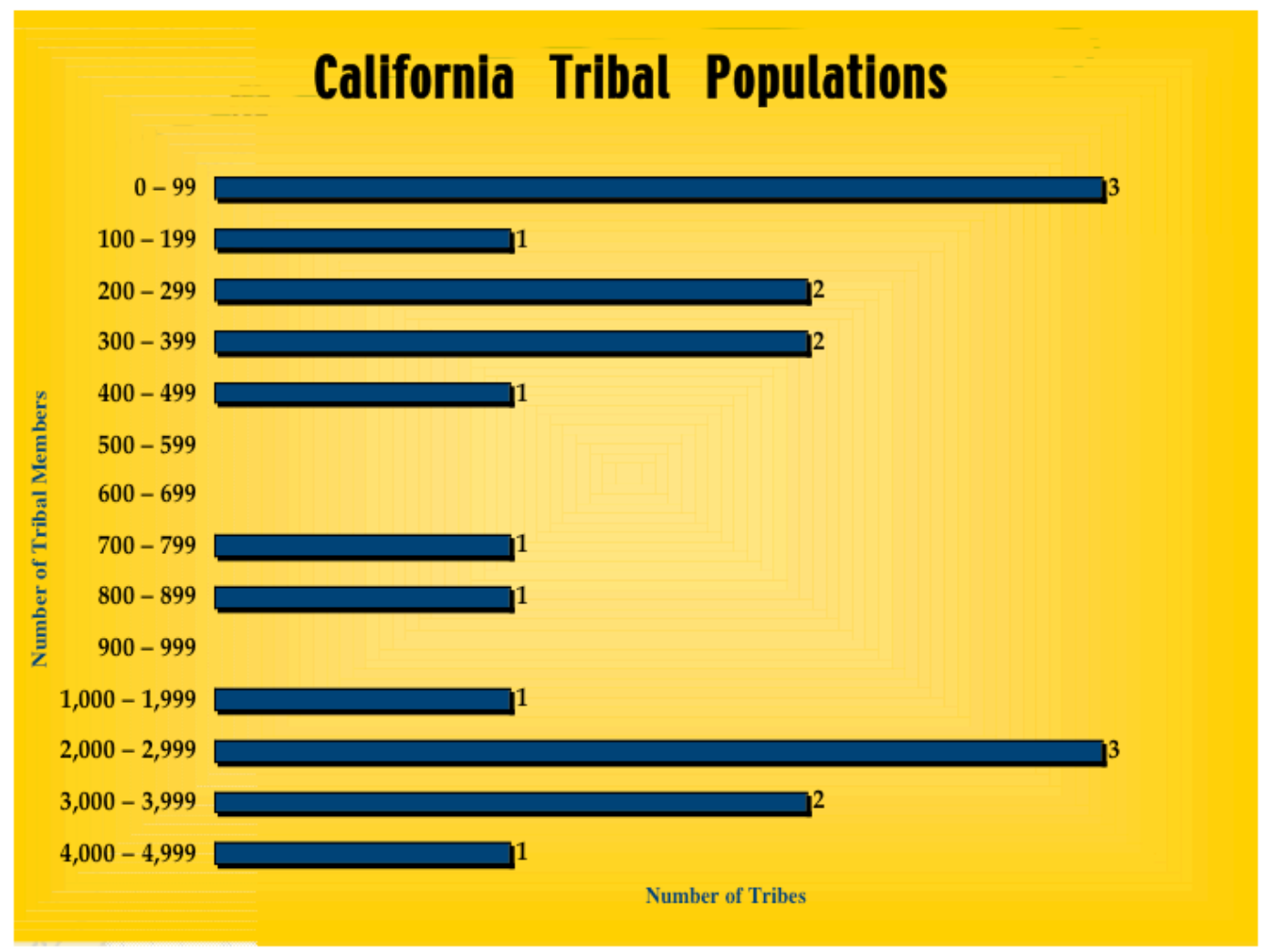




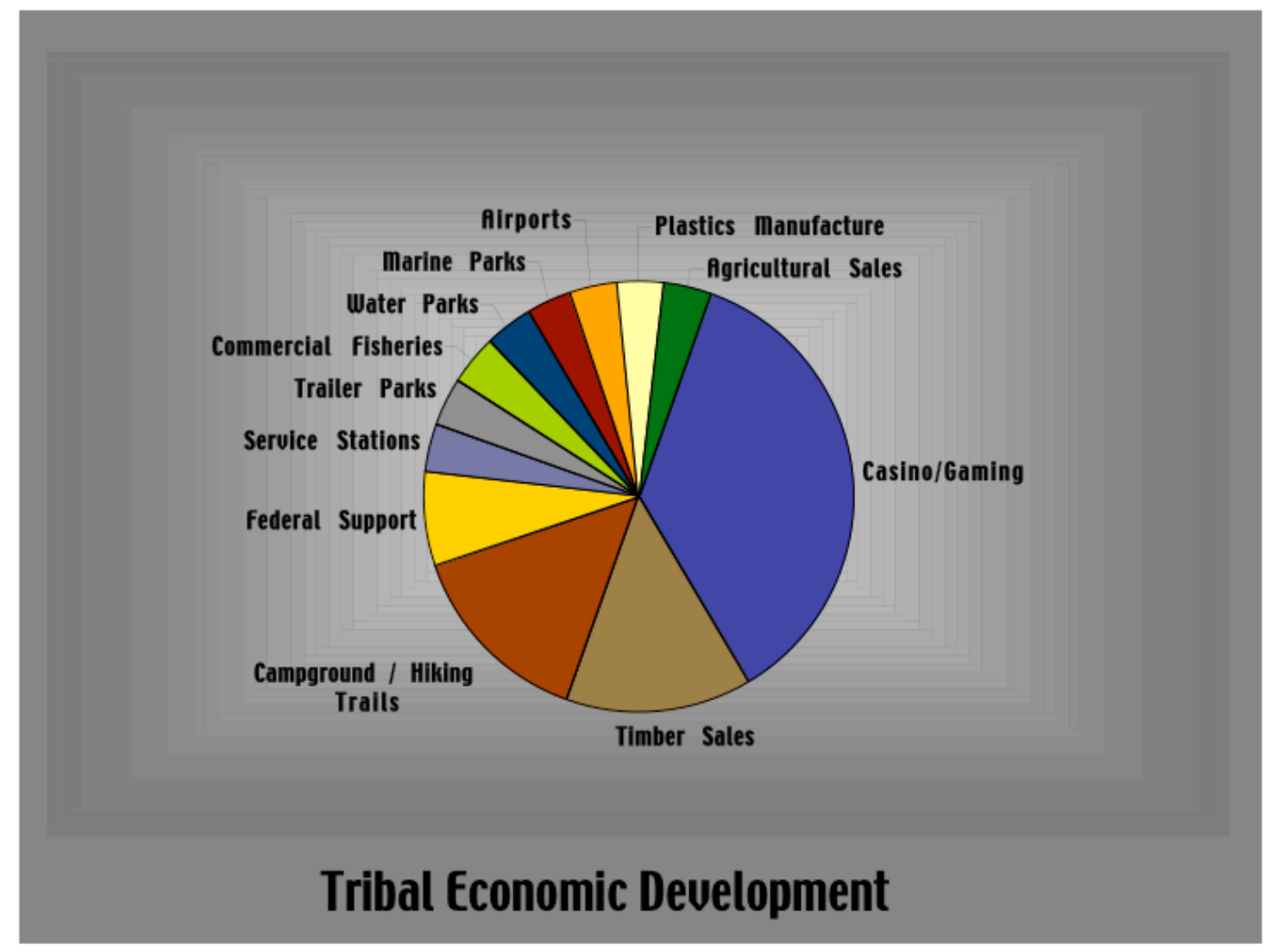




\section{Regional Tribal nations Water Issues [CA]}

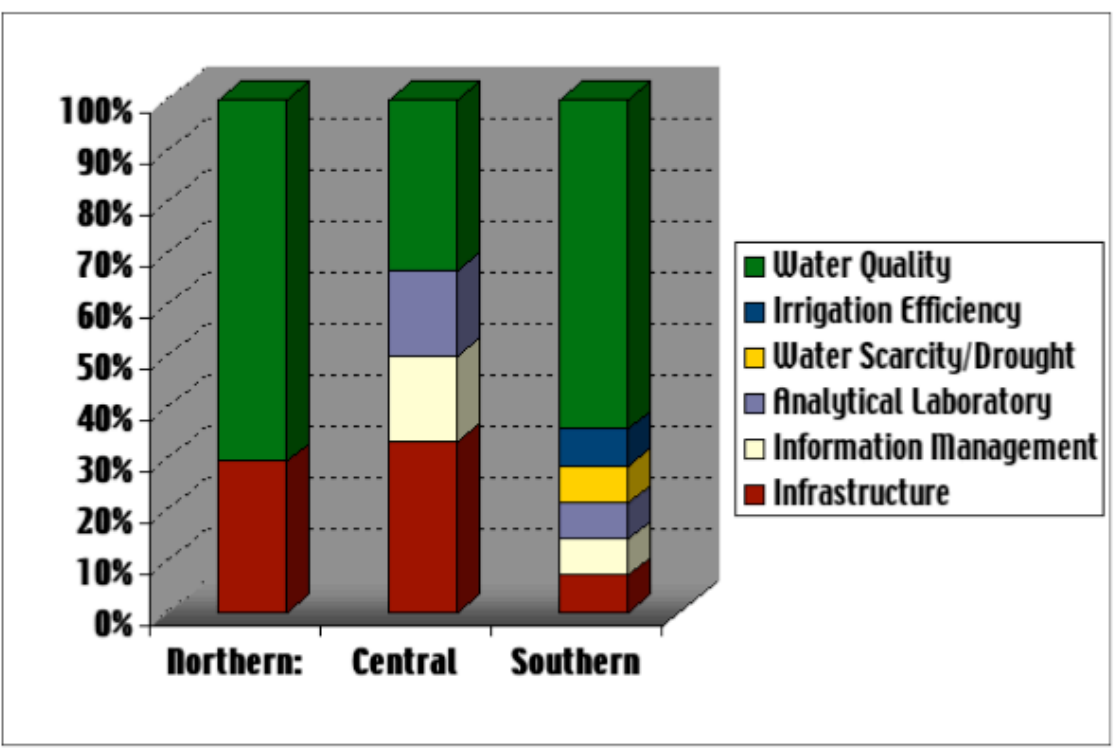




\section{Regional Key Water Issues}

* 18 Morthern frea Tribes

- Water Quality

- Infrastructure

* 55 Central frea Tribes

- Water Quality

- Infrastructure

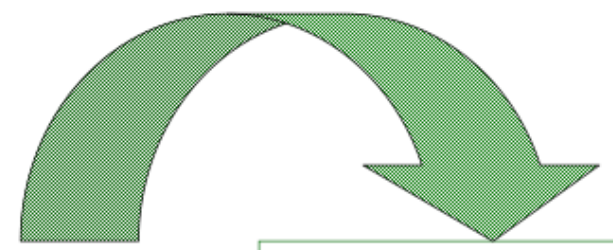

* 33 Southern Area Tribes

- Water Quality

- Diverse number of equally important water issues

-Pattern of water issues within regions influenced roundtable format proposal;

- need equal participation rather than tribes subject of roundtable. 


\section{Proposed Roundtable format}

*: Recommend one state-wide roundtable.

* May need 2 consecutive meetings due to cultural differences, trust issues, and relationship-building.

* Roundtable Objectives:

- Make goals of LLnL Water Initiative \& collaborations transparent;

- Discuss manner in which tribal nations 8 LLnL may partner on research issues (logistics, funding, sensitive research areas);

- Exchange of information (discussion of tribal issues \& LInL water resources);

- Identify any appropriate tribes that were inaduertently not invited;

- Receive feedback on potential collaborations and next steps. 


\section{Conclusions}

* A CA Tribal nations Technical Water Research Round Table adds an enhanced perspective to LLnL's Water Initiative.

* Discussions may lead to collaborations $\boldsymbol{\delta}$ partnerships in researching water issues.

* Federal funding may support partnerships between CA tribes and LInL for water research efforts.

* Water $\&$ Energy issues are typically linked for tribes, representing a wider breadth of potential collaborations.

* This project has the potential to be applied across the U.S. to remaining native fmerican tribes. 


\title{
Thank You for Your Attention
}

\author{
Questions?
}




\section{APPENDix E: Suggested Resources}

American Indian Resources Institute. Tribal Water Management Handbook: Building Homelands on $19^{\text {th }}$ Century Promises. Oakland, California.

Canbey, W.C. 1988. American Indian Law in a Nutshell, $2^{\text {nd }}$ edition. West Wadsworth.

Eargle, D. 2000. Native California Guide: Weaving the Past and the Present. Trees Company Press.

Helperin, A.N., et. al. 2001. California's Contaminated Groundwater: Is the State Minding. Natural Resources Defense Council.

Hundley, N. 2001. The Great Thirst: Californians and Water - A History, revised edition. University of California Press.

Johnson, M. 2001. Encyclopedia of Native American Tribes of North America. Gramercy.

Lewis, S.A. 1996. Sierra Club: Guide to Safe Drinking Water. Sierra Club Books.

Malinowski, S. and A. Sheets. 1998. The Gale Encyclopedia of Native American Tribes Vol. I-IV. Gale Group.

McCool, Daniel. 2002. Native Waters Contemporary Indian Water Settlements and the Second Treaty Era. University of Arizona Press.

Tribal Water Management Handbook: Building Homelands on $19^{\text {th }}$ Century Promises. Oakland, California: American Indian Resources Institute. 
Appendix F: Key Websites

California Environmental Protection Agency. State Water Resources Control Board Water Quality. Available at: http://www.swrcb.ca.gov/nps/protecting.html.

California Gambling Control Commission. Available at: http://www.cgcc.ca.gov/tribalcasinos.html.

Indian Gaming Links. Gaming Floor- Casino Trade and Industry News. Available at: http://www.gamingfloor.com/Indian links.html.

U.S. Census Bureau. Department of Commerce. Geographic Area: California American Indian Area. Available at:

http://factfinder.census.gov/servlet/GCTTable?ds name=DEC 2000 SF1 U\&geo i $\mathrm{d}=04000$ US06 \& box head nbr=GCT-PH1 \&format $=S T-8$.

U.S. Department of Agriculture. Natural Resources Conservation Services. Available at: http://www.nrcs.usda.gov.

U.S. Department of Health and Human Services. Indian Health Services. Available at:

http://www.ihs.gov/Publiclnfo/PublicAffairs/Welcome Info/ThisFacts.asp.

U.S. Environmental Protection Agency. Region IV: Indian Programs. Available at: www.epa.gov/region09/cross pr/indian/index.html.

U.S. Environmental Protection Agency. Region IV: Grants. Available at: http://www.epa.gov/region09/funding/index.html.

U.S. Environmental Protection Agency. American Indian Environmental Office. Tribal Grants. Available at: http://www.epa.gov/indian/tgrant.htm.

U.S. Department of Interior. Bureau of Reclamation. Water 2025 ConferencePreventing Crisis and Conflict in the West. Available at: http://www.doi.gov/water2025/conference/index.html 